\title{
Field Methods and Quality-Assurance Plan for Quality-of-Water Activities, U.S. Geological Survey, Idaho National Engineering and Environmental Laboratory, Idaho
}

By Roy C. Bartholomay, LeRoy L. Knobel, and Joseph P. Rousseau

U.S. GEOLOGICAL SURVEY

Open-File Report 03-42

Prepared in cooperation with

U.S. DEPARTMENT OF ENERGY

Idaho Falls, Idaho

January 2003 


\section{U.S. DEPARTMENT OF THE INTERIOR \\ GALE A. NORTON, Secretary}

\section{U.S. GEOLOGICAL SURVEY}

Charles G. Groat, Director

Any use of trade, product, or firm names is for descriptive purposes

only and does not imply endorsement by the U.S. Government.

For additional information write to:

U.S. Geological Survey

INEEL, MS 1160

P.O. Box 2230

Idaho Falls, ID 83403-2230
Copies of this report can be purchased from:

U.S. Geological Survey

Information Services

Box 25286, Denver Federal Center

Denver, CO 80225-0046 


\section{CONTENTS}

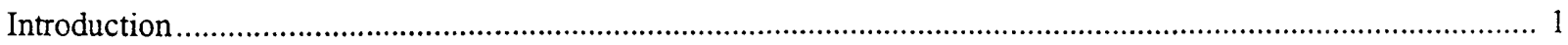

Purpose of and responsibility for maintaining the quality-assurance plan .............................................. 1

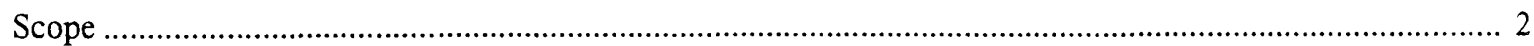

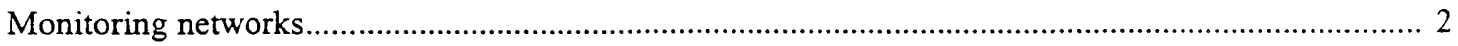

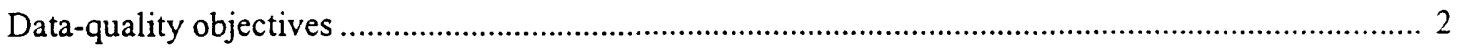

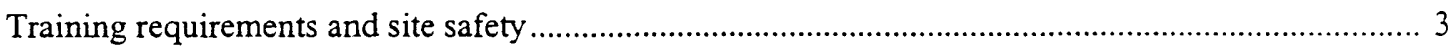

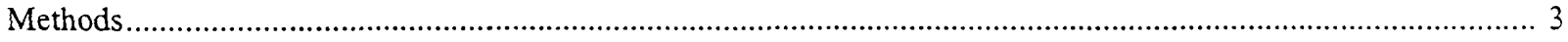

Sample containers and preservation methods ................................................................................... 3

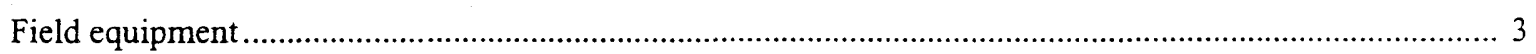

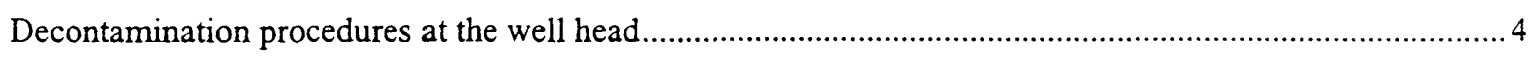

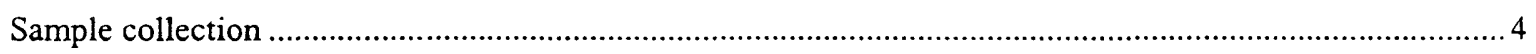

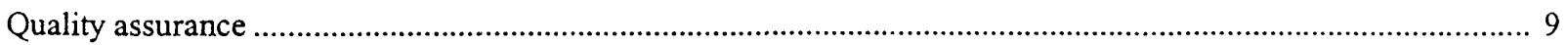

Analytical methods and quality-control samples ...................................................................................

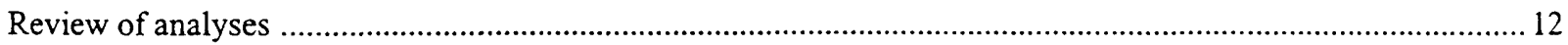

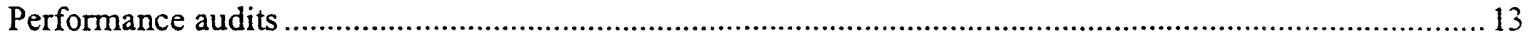

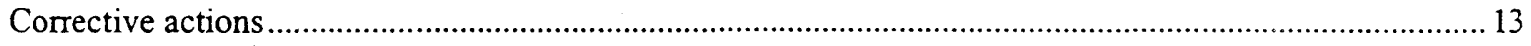

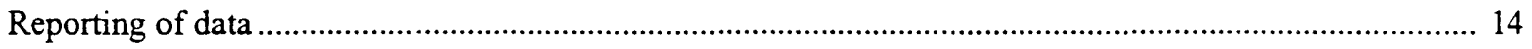

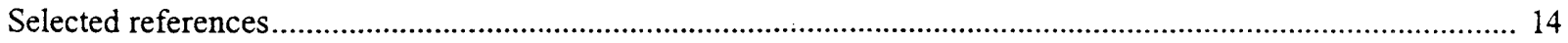

\section{FIGURES}

Figures 1-6. Examples of:

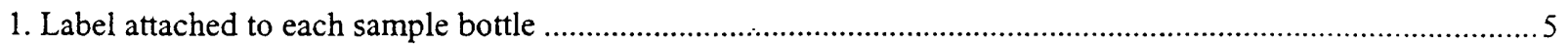

2. Analytical services request form for the National Water Quality Laboratory ..................................................... 6

3. Sample record sheet for the Radiological and Environmental Sciences Laboratory .......................................... 7

4. Sample request and chain-of-custody record for the Severn Trent Laboratory ................................................. 8

5. Sheet from Water-Quality Field Logbook ………......................................................................................... 10

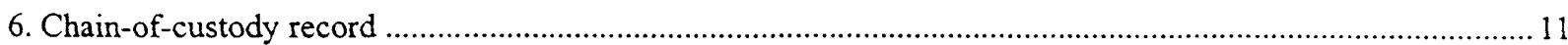

\section{TABLES}

1. Containers and preservatives used for water samples, Idaho National Engineering and Environmental

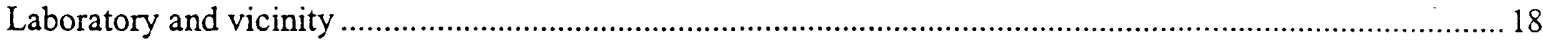

2. Maximum contaminant levels of types of radioactivity and selected radionuclides in drinking water............... 19

3. Maximum or secondary maximum contaminant levels and minimum reporting levels of selected trace

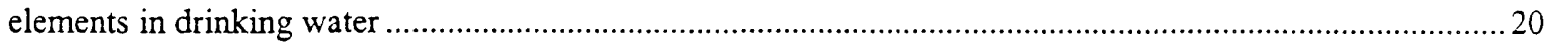

4. Maximum or secondary maximum contaminant levels and minimum reporting levels of selected common ions in drinking water. 
5. Maximum contaminant levels and minimum reporting levels of selected nutrients, organic carbon, and total organic halogens in drinking water

6. Maximum contaminant levels and minimum reporting levels of selected insecticides in drinking water

7. Maximum contaminant levels and minimum reporting levels of chlorophenoxy-acid herbicides and other herbicides in drinking water

8. Maximum contaminant levels and minimum reporting levels of selected purgeable organic compounds in drinking water

9. Detection limits for selected types of radioactivity and nuclides

10. Methods for analyses, minimum reporting levels, and method detection limits for constituents analyzed by Severn Trent Laboratories

\section{ATTACHMENTS}

1. Field schedule showing well and pump information and sampling schedules for selected wells and streamflow sites

2. Data-quality objectives for water samples analyzed by the National Water Quality Laboratory .37

3. Data-quality objectives for radionuclides in water samples analyzed by the Radiological and Environmental Sciences Laboratory .38

4. Data-quality objectives for water samples analyzed by the Severn Trent Laboratory 41

5. Inventory of water-quality field equipment

6. Auditor's checklist for quality-assurance field audits 


\title{
Field Methods and Quality-Assurance Plan for Quality-of-Water Activities, U.S. Geological Survey, Idaho National Engineering and Environmental Laboratory, Idaho
}

\author{
By Roy C. Bartholomay, LeRoy L. Knobel, and Joseph P. Rousseau
}

\section{INTRODUCTION}

Water-quality activities at the Idaho National Engineering and Environmental Laboratory (INEEL) Project Office are part of the U.S. Geological Survey's (USGS) mission of appraising the quantity and quality of the Nation's water resources. The activities are conducted in cooperation with the U.S. Department of Energy's (DOE) Idaho Operations Office and the U.S. Environment Protection Agency, Region 10. Results of the water-quality investigations are presented in various USGS publications or in refereed scientific journals. The results of the studies are highly regarded and are used with confidence by researchers, regulatory and managerial agencies, and interested civic groups.

In its broadest sense, quality assurance refers to doing the job right, the first time. It includes the functions of planning for products, review and acceptance of the products, and an audit designed to evaluate the system that produces the product. Quality assurance and quality control differ in that quality control ensures that things are done correctly given the "state-of-the-art" technology, and quality assurance ensures that quality control is maintained within specified limits.

\section{Purpose of and Responsibility for Maintaining the Quality-Assurance Plan}

The purpose of the Quality Assurance Plan (QAP) for water-quality activities performed by the INEEL Project Office is to maintain and improve the quality of technical products and to provide a formal standardization, documentation, and review of the activities that lead to these products. The principles of this plan are as follows:

1. Water-quality programs will be planned in a competent manner and activities will be monitored for compliance with stated objectives and approaches. The objectives and approaches are defined in an annual project work plan.

2. Field, laboratory, and office activities will be performed in a conscientious and professional manner in accordance with specified Water Resources Discipline (WRD) practices and procedures by qualified and experienced employees who are well trained and supervised. If or when WRD practices and procedures are inadequate, data will be collected in a manner such that its quality will be documented.

3. All water-quality activities will be reviewed for completeness, reliability, credibility, and conformance to specified standards and guidelines.

4. A record of actions will be kept to document the activities and the assigned responsibilities.

5. Remedial action will be taken to correct activities that are deficient.

The overall responsibility for maintaining this QAP belongs to the Chief of the INEEL Project Office. The principal investigators for geochemistry and the lead personnel for the waterquality monitoring network, however, are directly responsible for the day-to-day maintenance of the QAP. The QAP will be formally revised and reprinted every 2 to 5 years; changes that take 
place in the interim, however, will be communicated by memoranda to project-office personnel on an as-needed basis.

\section{Scope}

The QAP for water-quality activities at the INEEL defines procedures and tasks performed by project-office personnel that ensure the reliability of water-quality data. Virtually all of the principles of the plan have been in effect during past and current operations, but the QAP provides a method to formalize and communicate the plan to all employees of the project office and to users of the hydrologic data and interpretive reports. The plan was initially finalized in 1989. It was revised in March 1992 and again in 1996 (Mann, 1996). This report incorporates the revisions made to the program since 1996. A comprehensive list of references that contains guidelines used in data collection is given in the section entitled "Selected References." Tasks not described by the references owing to field conditions are detailed in the following sections.

Information on water-quality sampling schedules, data-quality objectives, and waterquality field equipment are included in attachments 1 through 5 .

\section{Monitoring Networks}

The water-quality monitoring network for the INEEL consists of about 170 sites and includes production wells, wells dedicated to water-quality monitoring, and surface-water sites. The network originally was established to document the distribution and concentration of radionuclides and industrial chemicals contained in wastewater discharged at the INEEL, either to the Snake River Plain aquifer or to the overlying perched groundwater zones. Disposal has taken place through deep disposal wells and shallow infiltration ponds. Additional monitoring sites will be selected if and when they are needed to better document the distribution and migration of solutes.

The frequency of sampling wells and streams in the INEEL network varies depending on the proximity of a particular sample site to a disposal site, the historical concentration of the radioactive or chemical waste in the water, and the location of the sample site relative to other sites. In general, water samples routinely are collected at 6-month to annual intervals. The wells and streams at which water samples are collected, the method and frequency of sample collection, and the constituents routinely analyzed for are shown on attachment 1 . In addition to the routine sampling, some wells periodically may be sampled for other constituents, including chlorine-36, iodine-129, trace metals, and purgeable organic compounds.

In addition to the 170 sites sampled for the routine program, the INEEL Project Office routinely collects water samples from 13 wells near the Naval Reactors Facility (NRF) approximately every 4 months. The purpose of this data-collection program is to provide the DOE's Pittsburgh Naval Reactors Office, Idaho Branch Office, with chemical and radiochemical data to evaluate the effect of NRF activities on the water quality of the Snake River Plain aquifer.

Also in addition to the routine program, the INEEL Project Office collects water samples from 41 wells and 5 springs between the southern boundary of the INEEL and the Hagerman area at 1- to 3-year intervals. This off-site water-quality network was established to monitor natural contaminants and anthropogenic pollutants in the aquifer that potentially could migrate from the INEEL to hydraulically downgradient populated and agricultural areas.

\section{Data-Quality Objectives}

Data-quality objectives are qualitative and quantitative criteria that describe the data needed by managers or regulators to support environmental decisions and actions or by scientists to study natural or induced chemical processes in the Snake River Plain aquifer. The first steps of the scientific method are somewhat analogous to and are supported by data-quality objectives. Identifying problems is followed by hypothesizing solutions. Unbiased and thorough scientific experiments are proposed and then conducted, analyzed, and reported in the literature for peer review and use by others. 
Data-quality objectives for water samples analyzed by the USGS's National Water Quality Laboratory (NWQL) are included in attachment 2; objectives for radionuclides in water samples analyzed by the U.S. Department of Energy's Radiological and Environmental Sciences Laboratory (RESL) are in attachment 3; and objectives for water samples analyzed by the Department of Defense Environmental Conservation (DODEC) contract laboratory are in attachment 4.

\section{Training Requirements and Site Safety}

Training and site safety are important components of the INEEL Project Office's QAP. Employees are not assigned tasks for which they are not adequately trained, and all employees have a stop-work authority if they feel work conditions are not safe. The responsibility for ensuring that employees are adequately trained is shared jointly by the employee and the employee's supervisor. A more detailed description of USGS INEEL Project Office personnel training requirements and site safety requirements are given in the USGS INEEL Site Safety and Job Hazard Analysis Document (Mann, 1995, written commun.).

\section{METHODS}

Sample containers, sample preservation methods, field equipment, and well-head decontamination and sample-collection procedures are integral and crucial steps in assuring that dataquality objectives are achieved at the field levei. Equally important are the analytical methods, and quality-control and quality-assurance activities exercised by the laboratories that analyze the samples.

\section{Sample Containers and Preservation Methods}

Sample containers and preservation methods differ depending on the chemistry of the constituents being analyzed. Samples analyzed by the NWQL are containerized and preserved in accordance with laboratory requirements specified by Timme (1995). Containers and chemical preservatives are supplied by the NWQL, where they undergo a rigorous quality control to ensure that they are free of contamination (Pritt, 1989, p. 75). Samples analyzed by the RESL are containerized and preserved in accordance with requirements specified by the laboratory's Analytical Chemistry Measurements Team; changes in procedures are documented in writing. Samples analyzed as part of the USGS DODEC program are containerized and preserved in accordance with requirements specified by the contract laboratory. Containers and preservatives for selected constituents are summarized on table 1.

\section{Field Equipment}

Analytical and other associated equipment used in the field include $\mathrm{pH}$ and specific-conductance meters, thermometers, multiparameter intruments, titrators for dissolved oxygen and alkalinity, a peristaltic pump, an in-line disposable filter capsule with a 0.45 -micron filter that is certified to be analyte free, and associated glassware. The analytical equipment is housed and usually operated in mobile field laboratories. The purpose of the mobile laboratories is threefold: (1) they provide a relatively clean area to measure field parameters while minimizing the potential for contamination or degradation of the samples from the wind, dust, rain, snow, and sunlight; (2) they are used as storage for sample and shipping containers, chemical reagents and preservatives, analytical instrumentation, and deionized water used for decontaminating equipment in the field; and (3) they provide a place where samples can be containerized, preserved, and placed in shipping containers within minutes after withdrawal from a well or stream.

Instruments used to measure field water-quality parameters, such as $\mathrm{pH}$ and specific conductance, are maintained and calibrated in the field or in the laboratory in accordance with procedures specified by the instrument manufacturer. Instrument calibration is checked and, if necessary, instruments are recalibrated at each sampling site; calibration documentation is permanently recorded in a field logbook. A logbook that documents changes to equipment-for example, modifications to $\mathrm{pH}$ and conductivity meters-is kept with each meter. An inventory of field equipment is given in attachment 5 . 


\section{Decontamination Procedures at the Well Head}

Wells that are equipped with dedicated submersible or line-shaft turbine pumps do not require decontamination except for the equipment that is attached to the discharge pipe to accommodate the collection of a water sample. Additionally, at least three wellbore volumes of water are pumped from the well to remove stagnant water and to rinse and equilibrate the pump and delivery line. Production wells generally have a spigot at or near the well head; decontamination consists of thoroughly rinsing the spigot with pumped ground water to remove foreign materials.

Sample collection is facilitated and excess water is diverted away from the well head by fitting wells equipped with dedicated pumps with a portable discharge pipe about $2 \mathrm{ft}$ long. The discharge pipe has a 1.5-in. I.D. (inside diameter) and is equipped with a gate valve to control the flow rate. A T-joint is inserted into the pipe between the well head and the control valve. A series of nipples, a valve to control the flow rate of the sampling port, and connectors are attached to the $\mathrm{T}$-joint to reduce the diameter so that a $1 / 4$-in. I.D. delivery line can be attached as a sampling point. The line is made up with two $1 / 4$-in. I.D. nipples connected with a 90 -degree elbow to facilitate sample collection. All fittings and pipes are stainless steel and are rinsed with deionized water before installation at the well head. Subsequent flushing with several hundred to thousands of gallons of purged well water further reduces the possibility of cross contamination with water from previously sampled wells. After sample collection, the fittings and pipes are rinsed with deionized water prior to storage to further reduce the chance of cross contamination between wells.

At wells that are not equipped with dedicated pumps, one of two methods is used to collect water samples, depending on the amount of water in the well and depth to water. A generatorpowered portable pump is used to collect the sample from wells at which the depth to water is less than $200 \mathrm{ft}$. The portable pump and attendant hose are decontaminated by flushing many cycles of water and detergent through them and then rinsing the equipment with tap water and then deionized water; 1.5 gal of water is enough to flush the pump and hose one time. Before the pump is installed in a well, it is thoroughly flushed by pumping deionized water through pump and discharge hose. Samples of the deionized-water rinsate periodically are collected and analyzed to document whether the portable pump is contaminated by constituents of interest.

For wells without dedicated pumps and at which the depth to water exceeds $200 \mathrm{ft}$, and for wells with only a few feet of water in the wellbore or wells that do not produce much water, a bailer is used for collecting water samples. The bailer and that part of the bailer line that enters the well are washed with hot water and detergent and rinsed with deionized water prior to use; samples of the rinsate periodically are collected and analyzed to document whether the equipment is contaminated by constituents of interest. At some wells, bailers are dedicated to and stored in the well casing. This eliminates the possibility of cross contamination of samples from different wells.

\section{Sample Collection}

Sample collection by the USGS at the INEEL generally follows protocols established by Wilde and others (1998); however, protocols sometimes are modified to collect the best representative water sample possible. At wells equipped with a dedicated pump or at which a portable pump is used to ensure that water representative of the Snake River Plain aquifer or perched ground-water zone is sampled, a volume of water equivalent to a minimum of 3 wellbore volumes is pumped prior to collecting the samples; at many wells, 5 to 10 wellbore volumes are pumped. The diameter of the wellbore, rather than the volume of the casing is used to calculate the minimum volume because of the potentially large difference between the two. In addition, temperature, specific conductance, and $\mathrm{pH}$ are monitored periodically during pumping using methods described by Wood (1981) and Hardy and others (1989). Field measurements made immediately prior to sample collection are used to represent those for the sample. When these 
measurements stabilize, indicating probable hydraulic and chemical stability, a water sample is collected using the following steps:

1. The field person responsible for collecting the water sample wears disposable gloves and stands in a position where neither the collector nor the sample can become contaminated.

2. The outside of the sample delivery line is thoroughly rinsed with water pumped from the well.

3. If appropriate, sample containers and filtration equipment are thoroughly rinsed with water pumped from the well or surface-water site before being used. A new, disposable capsule filter with a 0.45 -micron membrane filter is used at each site. The capsule filter is inverted to clear trapped air bubbles and one liter of deionized water or water from the well is used to rinse the capsule filter prior to sample collection. This removes any surfactants that are adhered to the filter.

4. For ground-water samples from wells equipped with dedicated pumps, the capsule filter is connected to the sample port with precleaned Tygon tubing; unfiltered samples are collected directly from the sample port. For surface-water samples and bailer samples, a grab sample is collected in a pre-cleaned container and the inlet tubing of a peristaltic pump is placed into the container to supply sample water to the capsule filter. Unfiltered samples are collected by submersing the sample container into the surfacewater body or drawing water from a precleaned container.

5. Samples are capped and moved into the mobile field laboratory where they are uncapped and preserved (if appropriate) as described in table 1. A new pair of gloves, safety glasses, and a lab apron are worn while preserving samples.

6. The bottles are capped and the caps are sealed with laboratory film. The bottles then are labeled (see fig. 1 for example of label). An alternate method for labeling containers is to record information directly on the sample container using a permanent marker. Recording the information both on a label and directly on the bottle is the preferable option.

\begin{tabular}{ll}
\hline LOCATION $=$ & 1 OF 1 \\
STA NAME $=$ & SPEC COND $=$ \\
DATE $=$ & TIME $=$ \\
SAMP SIZE $=$ & pH $=$ \\
DISCHAGE $=$ & TREATMENT $=$ \\
W TEMP $=$ & A TEMP $=$ \\
SAMPLE TYPE $=$ & SCHEDULE $=$
\end{tabular}

Figure 1. Label attached to each sample bottle.

7. Field measurements are made again after samples are collected. If the temperature differs by more than $0.5^{\circ} \mathrm{C}$, the $\mathrm{pH}$ differs by more than 0.1 units, or the conductance differs by more than 5 percent, the measurements are verified and a second set of samples are collected.

8. A laboratory request schedule is completed for use by each laboratory to which the sample(s) will be sent for analysis (see figs. 2-4 for examples). .

9. The water samples are chilled to $4{ }^{\circ} \mathrm{C}$ if necessary, and stored in the field laboratory until they can be transferred to a secured storage area. Samples are transported to the analyzing laboratory as soon as reasonably possible. Samples sent to the NWQL for analysis are transported in a sealed ice chest by a contract carrier; overnight delivery is stipulated for water samples for analyses of nutrients, total organic carbon, and purgeable organic compounds. Samples sent to the RESL for analysis are hand carried to the laboratory. Samples for the DODEC contract laboratory, with short holding times, are shipped by overnight delivery on the same day as the sampling.

10. All equipment is decontaminated with deionized water and, if necessary, organic-free water.

Some wells completed in the perched-water zones do not contain or produce enough water to be sampled with a portable pump. For these wells, either a 1,000-mL Teflon bailer or a 1,000-mL galvanized bailer normally is used for sample collection. The well is bailed until enough water is collected for all the samples required or until the well is bailed dry. When the bailer is retrieved, its 


\section{U.S. GEOLOGICAL SURVEY - NATIONAL WATER QUALITY LABORATORY \\ ANALYTICAL SERVICES REQUEST}

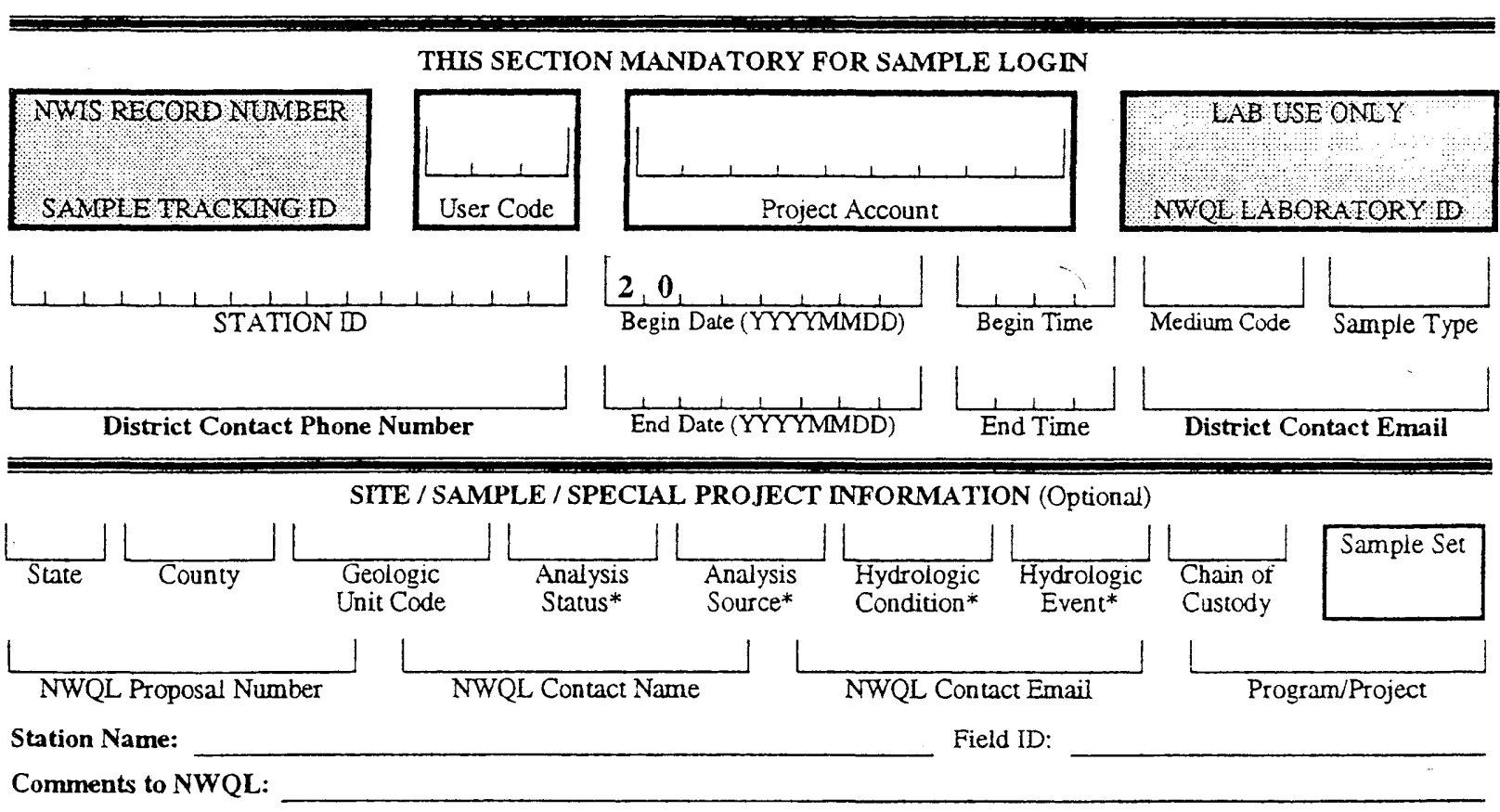

Hazard (please explain):

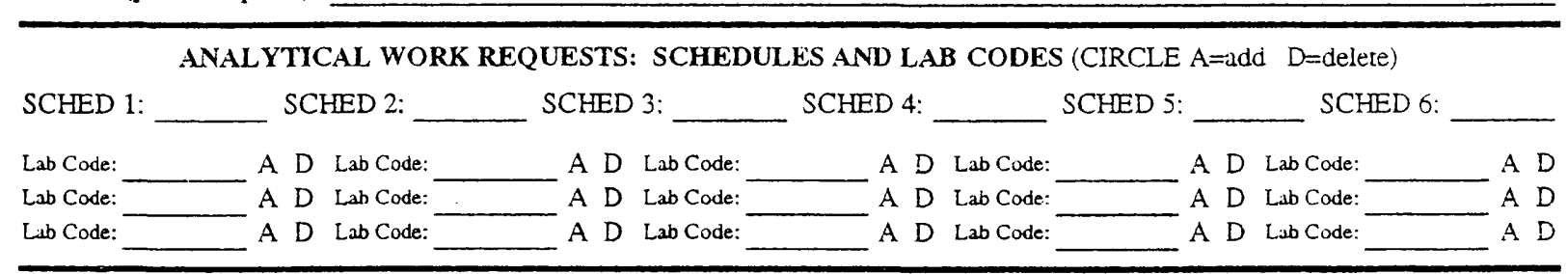

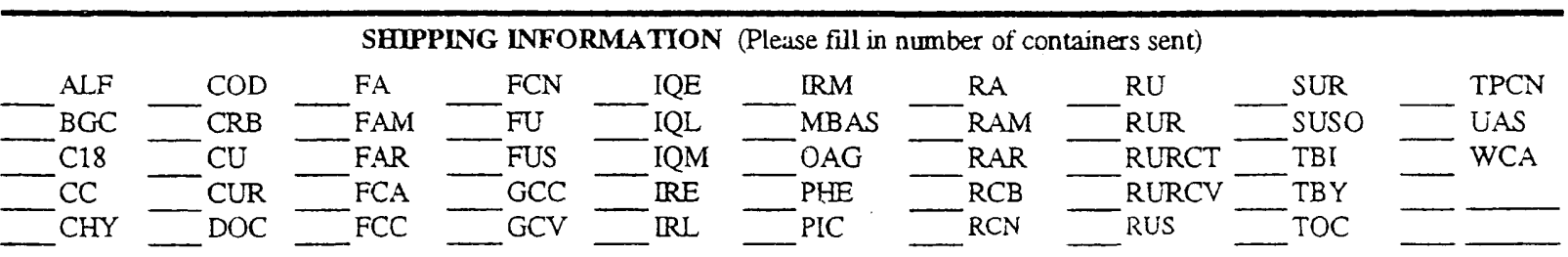

NWQL Login Comments:

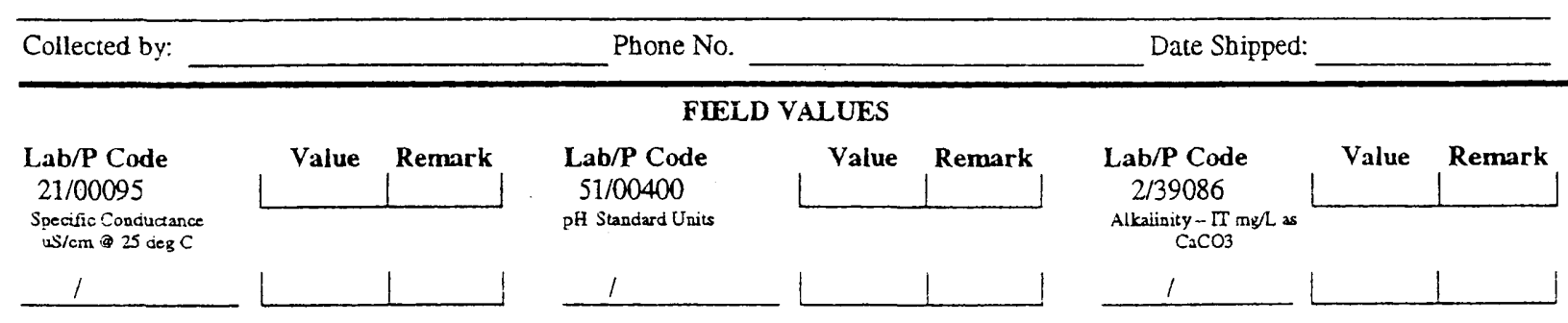

Field Comments:

*MANDATORY FOR NWIS

Figure 2. Analytical services request form for the National Water Quality Laboratory. 
UNITED STATES DEPARTMENT OF ENERGY

IDAHO OPERATIONS OFFICE

Routine

RADIOLOGICAL AND ENVIRONMENTAL SCIENCES LABORATORY

Non-Routine___ Date Needed SAMPLE RECORD SHEET
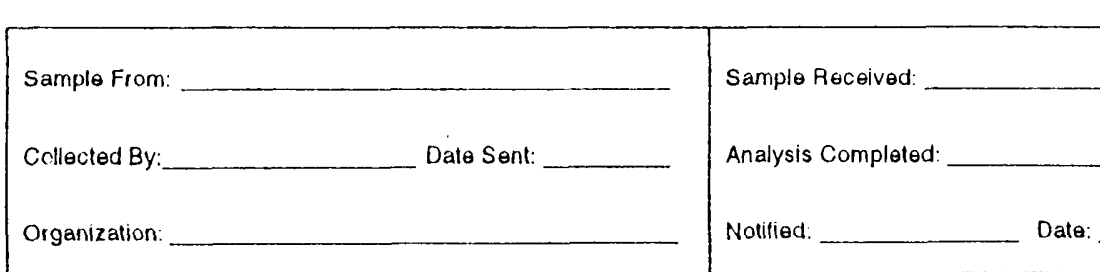

\begin{tabular}{|c|c|c|c|c|c|c|}
\hline Anal. & Inst. & Quant & Date & Count & Gross & BKGD. \\
\hline
\end{tabular}

No.

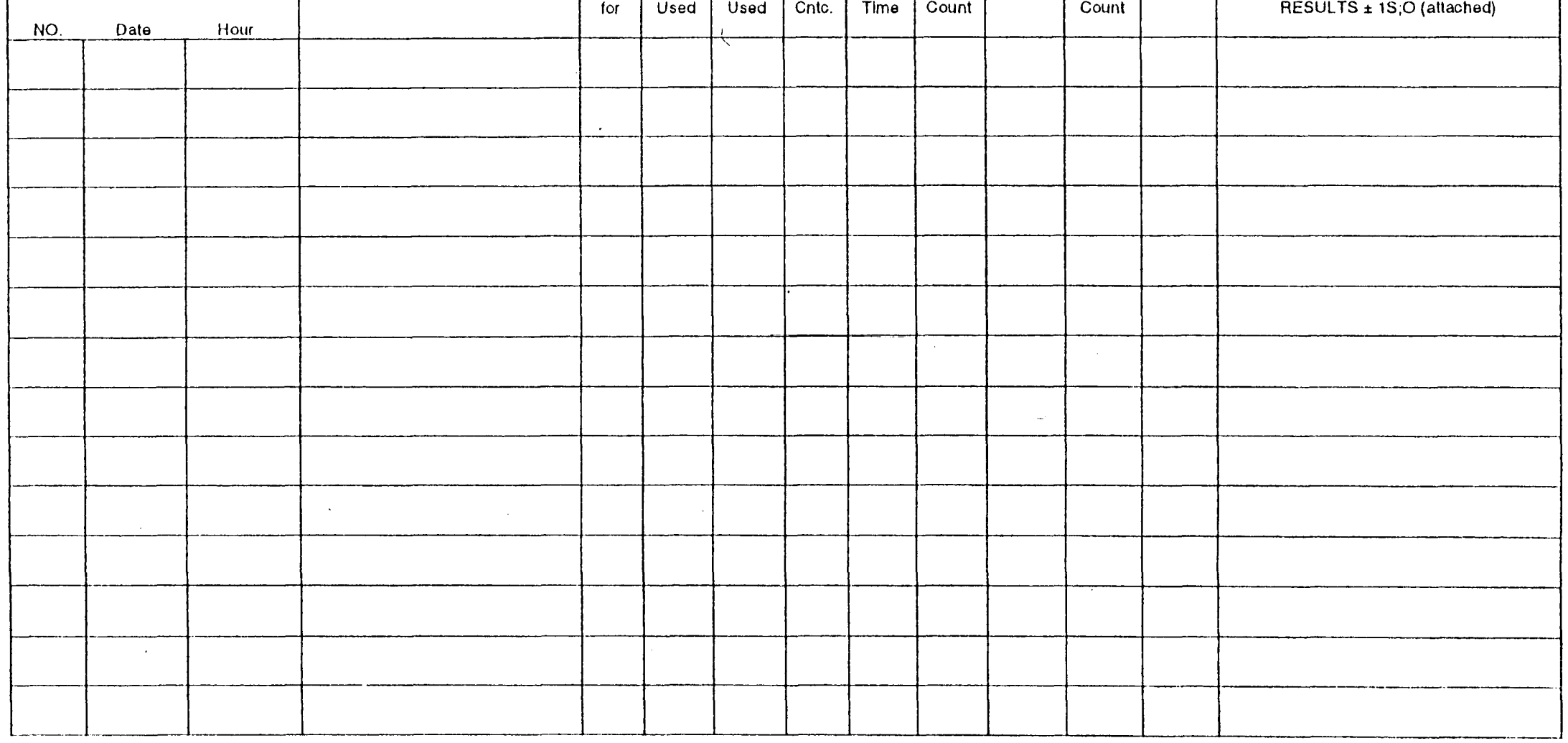

Figure 3. Sample record sheet for the Radiological and Environmental Sciences Laboratory. 


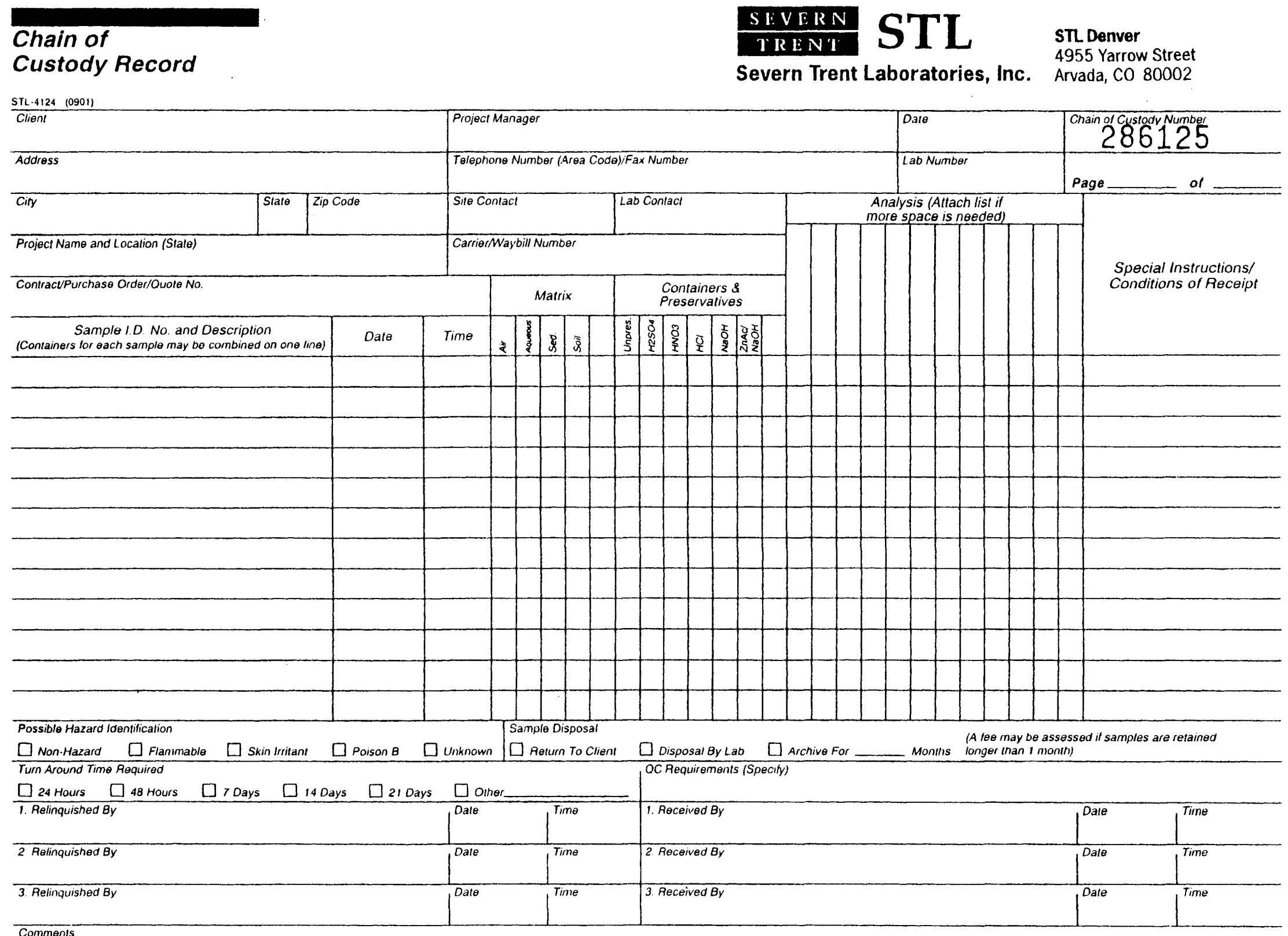

Comments

DISTAIBUTION: WHITE - Returned to Client with Regont: CANAAY - Stays with the Sample: PINK - Field Copy

Figure 4. Sample request and chain-of-custody record for the Severn Trent Laboratory. 
contents either are placed directly in bottles for raw samples or in a precleaned container as described in step 4. Field measurements are made on excess water from the bailer or in the precleaned container. After the sample bottle is filled with either raw or filtered water, samples are preserved appropriately and labeled, stored, and shipped as described in steps 6-9.

One perched-water well contains enough water to use a portable pump but because of a low recovery rate the well pumps dry before two or three wellbore volumes can be pumped. For this well, a sample is collected when temperature, $\mathrm{pH}$, and specific conductance measurements stabilize. If the well pumps dry before measurements stabilize, the field person waits for the well to recover to collect a pumped or bailed sample or, if the well does not recover, a grab sample is collected from the prerinsed bucket into which water is discharged while pumping. Exceptions such as these to usual sample-collection procedures are described in the field logbook.

Wells inside the Test Reactor Area and the INEEL Comprehensive Environmental Response, Compensation and Liability Act Disposal Facility (ICDF) require containerization of all purge water. These wells are purged at slow rates to minimize the amount of purge water. After three stable readings of temperature, $\mathrm{pH}$, and specific conductance are obtained, they are sampled.

An added precaution against cross contamination is used at wells that are sampled with a portable submersible pump or bailer. The concentrations of most contaminants are greatest in wells nearest disposal sites and decrease with increasing distance. Therefore, when conditions permit, the most distant wells are sampled first. This method of sampling minimizes the potential for cross contamination.

Conditions at the well during sample collection are recorded in a bound field logbook (fig. 5) and a chain-of-custody record (fig. 6) is used to track samples from the time of collection until delivery to the RESL or until mailing to the NWQL. These records are available for inspection at the USGS
INEEL Project Office. The chain-of-custody record for the current DODEC contract laboratory, Severn Trent Laboratories, is shown in figure 4.

\section{QUALITY ASSURANCE}

The USGS's Quality-Assurance Program at the INEEL Project Office incorporates the previously described methods of sample collection and processing with several other elements: (1) analytical methods used by the laboratories; (2) quality-control samples; (3) review of analytical results of chemical constituents provided by the laboratories; (4) audits of performance in the field and in the laboratory; (5) corrective actions to resolve problems with field and laboratory methods; and (6) reporting of data. These elements effectively are performed to assure the following: (1) reliability of the water-quality data; (2) compatibility of the data with data collected by other organizations at the INEEL; and (3) the data meet the programmatic needs of the DOE and its contractors and the scientific and regulatory communities.

\section{Analytical Methods and Quality-Control Samples}

A detailed description of internal quality control and of the overall quality-assurance practices used by the NWQL is provided in reports by Friedman and Erdmann (1982) and Pritt and Raese (1995); quality-control practices at the laboratory are described by Jones (1987); and quality-assurance data for routine water analyses are presented in a report by Maloney and others (1993). Additional quality assurance instituted by the INEEL Project Office includes collection and analysis of the following: (1) duplicate samples-two or more samples collected concurrently or sequentially and sent to different laboratories; (2) blind replicates-duplicate samples with different sample identification numbers submitted to a laboratory; (3) blank samples-samples of deionized water sent to a laboratory and identified as routine samples; (4) equipment blanks-rinsate collected during decontamination procedures; (5) splits-large sample volumes divided into two or more equal volumes and sent to different laboratories for 
Date :

Site Id No: Site Id

Purpose of Sampling:

Type of Sample (circle one): Ground water Surface water other

Number of Containers:

Size of Containers/Method of Preservation:

Laboratory Schedules Requested:

Descriptions of Sampling Point:(82398)

Equip. Serial Nos: $\mathrm{pH}$ Specific cond.

Other (specify)

Instrument Calibrations:

Specific cond. Yes No Value of standard Solution

$\mathrm{pH} \quad$ Yes No Number of Buffers___Values of Buffers

Other (specify)

Equipment Maintenance:

Decontamination Procedures:

Field Measurements: Sampling Agency (00027) = USGS (1028)

Water Temp ${ }^{\circ} \mathrm{C}(00010)=$ $\mathrm{pH}(00400)=$ Sp.C. us $/ \mathrm{cm}(00095)=$

A.k.as $\operatorname{CaCO} 3(00410)=$ $\mathrm{DO}(00300)=$ Turb. $(00076)=$

$\operatorname{Other}(\mathrm{s})$

References (maps, etc.) :

Name and Affiliations of Observers:

1.

2 .

Field Observations (notes, photos, drawings, pumping period and rate, etc.):

Pump on a

$\mathrm{WL}=$ $T D=$

Dia $=$ $Q=$

$\mathrm{Min} / \mathrm{Vol}=$

RESL @

Latitude

Longitude

Comments :

Collector's Names (please print), Signatures, and Date:

Name

Name

Name Signature

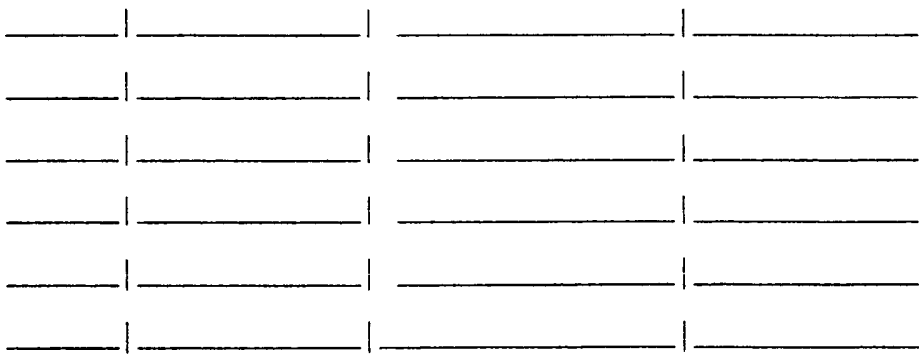

Signature_Date

Date

Date

Figure 5. Sheet from Water-Quality Field Logbook. 


\section{Zuses}

U.S. Geological Survey

INEEL CF 690 Room 173

Scoville, IDAHO 83415

Page___ of

Proj No.

CHAIN OF CUSTODY RECORD pages

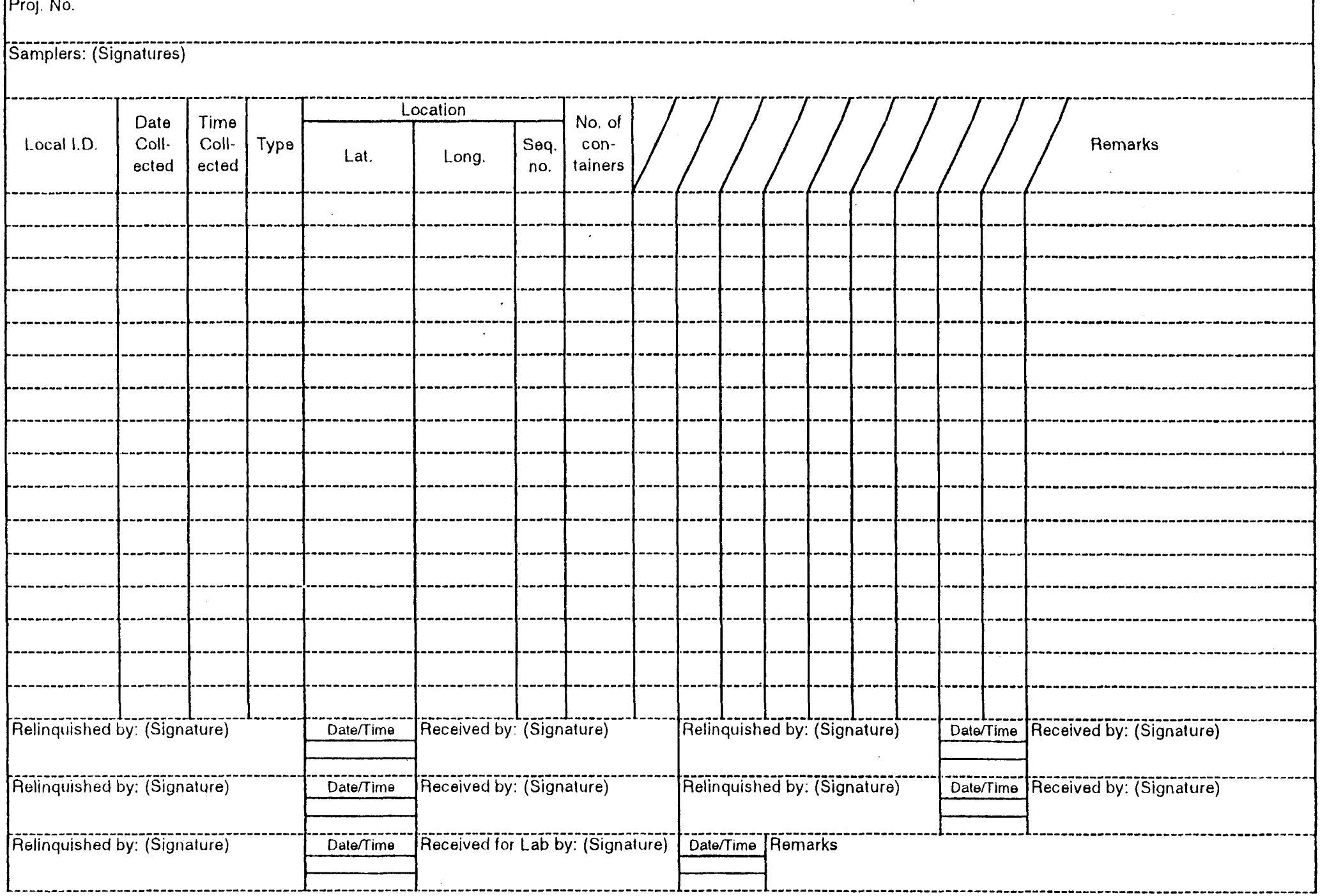

Figure 6. Chain-of-custody record. 
analysis; (6) trip blanks-laboratory supplied samples of boiled deionized water that travel with water samples from time of collection to time of analysis; and (7) spiked samples-samples to which a known concentration of a constituent is added. Analytical methods used by the NWQL are described by Faires (1992), Fishman (1993), Fishman and Friedman (1989), Goerlitz and Brown (1972), Rose and Schroeder (1995), Thatcher and others (1977), and Wershaw and others (1987). The type of analysis and analytical procedure are specified on the NWQL services request form (fig. 2).

A discussion of procedures used by the RESL for the analysis of radionuclides in water is provided in reports by Bodnar and Percival [eds.] (1982) and U.S. Department of Energy (1995). Additional quality assurance implemented by the INEEL Project Office for samples sent to the RESL is consistent with procedures used for samples sent to the NWQL. The type of analysis to be performed on a water sample is specified on the RESL sample record sheet (fig. 3).

A discussion of procedures used by the current DODEC contract laboratory, Severn Trent Laboratories, is provided in a report by Quanterra Environmental Services (1998). Quality-assurance samples for each NRF DODEC sampling round includes field-blank and replicate samples. A tripblank sample for purgeable organic compound analysis is collected annually. The type of analysis to be performed on a water sample is specified on the contract laboratory sample request sheet (fig. 4).

In general, about 10 percent of the samples collected are dedicated to quality assurance. That is, for every 10 samples submitted to one of the laboratories for analysis, at least one is a blind replicate, a blank, a split, or another type of quality-assurance sample. For samples that are to be analyzed for non routine constituents, 15 to 20 percent of the samples are dedicated to quality assurance.

Comparative studies to determine agreement among analytical results for water-sample pairs analyzed by laboratories involved in the INEEL Project Office quality-assurance program are summarized by Wegner (1989), Williams (1996, 1997), and Williams and others (1998). Additional quality-assurance studies by personnel at the INEEL Project Office include an evaluation of field-sampling and preservation methods for strontium-90 (Cecil and others, 1989), a comparison of different pump types used for sampling purgeable organic compounds (Knobel and Mann, 1993), an analysis of tritium and strontium-90 concentrations in water from wells after purging different borehole volumes (Bartholomay, 1993), an analysis of the effect of different preservation methods on nutrient concentrations (Bartholomay and Williams, 1996), and an analysis of two analytical methods for the determination of gross alpha- and beta-particle radioactivity (Bartholomay and others, 1999).

\section{Review of Analyses}

After the analytical results are obtained from the analyzing laboratory, the concentration of each constituent of interest is reviewed by personnel at the INEEL Project Office for consistency, precision, and accuracy. Factors considered during the review are:

1. The historical concentration of the solute at the site where the sample was collected;

2. The concentration of the solute in replicate, split, blank, or other quality-assurance samples;

3. The concentration of the solute in nearby wells that obtain water from the same aquifer or perched-water zone;

4. A review of waste-disposal records and changes in disposal techniques, land use, and recharge that may influence the concentration of a solute(s);

5. Cation-anion balance of analyses for which common ions are analyzed; and

6. Other accepted tests for accuracy of analytical results, when appropriate (Hem, 1985, p. 163-165).

Constituents for which previous analyses have been made are reviewed for consistency with items 1,2 , and 3 . If a constituent exceeds or is less than the historical data, if it differs markedly from the 
concentration in water from nearby wells, or if an initial analysis for a solute exceeds 80 percent of the maximum contaminant level (MCL) for that constituent set by the Environmental Protection Agency, either a re-analysis by the laboratory is requested or a second sample is collected and analyzed to verify the concentration of the solute in the water. If resampling is necessary, replicates generally are collected to evaluate laboratory precision. Constituents for which MCLs have been proposed or established are shown on tables 2-8.

If analytical results indicate that concentrations in samples from one site vary by more than 50 percent for no obvious reason, the results are evaluated by replicate sampling. If the analytical results for the replicates do not agree, the analyzing laboratory is contacted to resolve the problem.

\section{Performance Audits}

Performance audits are conducted routinely at three levels: (1) at the field level, (2) at the laboratory level, and (3) through National Field Quality Assurance Tests. At the field level, the Project Chief or a designee routinely accompanies the field personnel to a selected number of sites to ascertain whether proper field techniques are used to collect and preserve the samples and to ensure safety procedures. The field auditor's checklist is given in attachment 6 . Replicate and split samples are used to evaluate the precision of the field and laboratory methods; spikes and reference samples are used to measure accuracy.

The INEEL Project Office participates in the National Field Quality Assurance Program established by the USGS to evaluate the accuracy of water-quality field measurements. Qualityassurance samples are sent to field personnel for testing. The results are sent back to the waterquality service unit for evaluation. If field personnel or equipment do not pass the test, corrective action is taken. The program is described in detail by Erdmann and Thomas (1985).

In addition to the routine performance audits, water-quality activities at the INEEL Project Office periodically are monitored and reviewed by other USGS personnel; the Water-Quality Specialist for the Idaho District, Boise, Idaho; personnel at the Office of the Regional Hydrologist, Western Region, Menlo Park, Calif.; and personnel at the Office of Water Quality at Headquarters, Reston, Va. Reviews by personnel at the Idaho District take place at 1- to 2-year intervals and by the Western Region Office and Office of Water Quality at 2- to 3-year intervals. The reviews are summarized in writing and distributed to the Project Office, Regional Office, and the Office of Water Quality. If deficiencies are documented, a written reply outlining corrective action is required by the Project Office.

\section{Corrective Actions}

If the performance audits indicate inconsistencies or inadequacies in field methods or in analytical results by the laboratories, the problems are documented and the field personnel or laboratories are notified in writing of the inconsistencies or inadequacies. Training is provided to the field personnel as needed and the frequency of performance audits is increased until the performance is judged by the INEEL Project Office Chief as suitable and consistent with written guidelines.

Inconsistencies and inadequacies in laboratory analyses are discussed with or submitted in writing to the appropriate laboratory director, who is responsible for initiating the appropriate action to resolve the problem. To evaluate whether appropriate actions are taken, the frequency and numbers of replicate, blank, split, or other qualityassurance samples are increased until it is demonstrated that problems in the laboratory methods are resolved.

If project-office personnel discover a problem with sampling procedures, equipment calibration, or data review analysis and interpretation that cannot be resolved at the project level, the Idaho District Water-Quality Specialist is notified of the problem. If he or she cannot resolve the problem in consultation with the Regional Water-Quality Specialist, the problem may be referred to the Office of Water Quality or National Research Program, where research hydrologists and chemists will aid in resolving the problem. 


\section{Reporting of Data}

All data collected by the USGS INEEL Project Office are publically available, after review, and most data are published in data reports and used in interpretive reports. Water-quality information, subsequent to its review, is entered into the National Water Information System (NWIS) and periodically merged with a nationally-accessible database. Data that suggest that there could be a human health or environmental problem are provided to managerial agencies such as the DOE and to regulatory agencies, such as the State of Idaho's Department of Health and Welfare and the U.S. Environmental Protection Agency, Region 10. After data have been reviewed and verified by resampling if necessary, they are available to the general public either upon request or through the USGS public web page at http://waterdata.usgs.gov/nwis.

\section{SELECTED REFERENCES}

Bartholomay, R.C., 1993, Concentrations of tritium and strontium-90 in water from selected wells at the Idaho National Engineering Laboratory after purging one, two, and three borehole volumes: U.S. Geological Survey WaterResources Investigations Report 93-4201 (DOE/ID-22111), $21 \mathrm{p}$.

Bartholomay, R.C., Hill, G.H., and Randolph, R.B., 1999, Statistical comparison of gross alpha- and gross beta-particle activity in water analyzed using two analytical methods [abs.]: Rocky Mountain Conference on Analytical Chemistry, 41 st, Denver, Colo., 1999 Program and Abstracts, p. 132.

Bartholomay, R.C., and Williams L.M., 1996, Evaluation of preservation methods for selected nutrients in ground water at the Idaho National Engineering Laboratory, Idaho: U.S. Geological Survey Water-Resources Investigations Report 96-4260 (DOE/ID-22131), 16 p.
Bodnar, L.Z., and Percival, D.R., eds., 1982, Analytical Chemistry Branch procedures manual-Radiological and Environmental Sciences Laboratory: U.S. Department of Energy Report IDO-12096 [variously paged].

Cecil, L.D., Knobel, L.L., Wegner, S.J., and Moore, L.L., 1989, Evaluation of field sampling and preservation methods for strontium90 in ground water at the Idaho National Engineering Laboratory, Idaho: U.S. Geological Survey Water-Resources Investigations Report 89-4146 (DOE/ID-22083), 24 p.

Claassen, H.C., 1982, Guidelines and techniques for obtaining water samples that accurately represent the water chemistry of an aquifer: U.S. Geological Survey Open-File Report 82$1024,49 \mathrm{p}$.

Currie, L.A., 1968, Limits for qualitative detection and quantitative determination-application to radiochemistry: Analytical Chemistry, v. 40 , no. 3, p. 586-593.

Erdmann, D.E., and Thomas, J.D., 1985, Quality assurance of the U.S. Geological Survey water-quality field measurements, in Taylor, J.K., and Stanley, T.W., eds., Quality assurance for environmental measurements: American Society for Testing and Materials Special Technical Testing Publication 867, p. 110 115.

Faires, L.M., 1992, Methods of analysis by the U.S. Geological Survey National Water Quality Laboratory-determinations of metals in water by inductively coupled plasma-mass spectrometry: U.S. Geological Survey OpenFile Report 92-634, 28 p.

Fishman, M.J., ed., 1993, Methods of analysis by the U.S. Geological Survey National Water Quality Laboratory-determination of inorganic and organic constituents in water and fluvial sediments: U.S. Geological Survey Open-File Report 93-125, 217 p.

Fishman, M.J., and Friedman, L.C., 1989, Methods for determination of inorganic substances in water and fluvial sediments: U.S. Geological Survey Techniques of Water-Resources Investigations, book 5, chap. A1, 545 p. 
Friedman, L.C., and Erdmann, D.E., 1982, Quality assurance practices for the chemical and biological analyses of water and fluvial sediments: U.S. Geological Survey Techniques of Water-Resources Investigations, book 5 , chap. A6, 181 p.

Garbarino, J.R., 2000, Methods of analysis by the U.S. Geological Survey National Water Quality Laboratory - determination of wholewater recoverable arsenic, boron, and vanadium using inductively coupled plasma-mass spectrometry: U.S. Geological Survey OpenFile Report 99-464, 15 p.

Garbarino, J.R., and Damrau, D.L., 2001, Methods of analysis by the U.S. Geological Survey National Water Quality Laboratory-determination of organic plus inorganic mercury in filtered and unfiltered natural water with cold vapor-automatic fluorescence spectrometry: U.S. Geological Survey Water-Resources Investigations Report 01-4132, $16 \mathrm{p}$.

Garbarino, J.R., and Hoffman, G.L., 1999, Methods of analysis by the U.S. Geological Survey National Water Quality Laboratory-comparison of a nitric acid in-bottle digestion procedure to other whole-water digestion procedures: U.S. Geological Survey OpenFile Report 99-094, 21 p.

Garbarino, J.R., and Struzeski, T.M., 1998, Methods of analysis by the U.S. Geological Survey national Water Quality Laboratory-determination of elements in whole-water digests using inductively coupled plasma-optical emission spectrometry and inductively coupled plasma-mass spectrometry: U.S. Geological Survey Open-File Report 98-165, 101 p.

Goerlitz, D.F., and Brown, Eugene, 1972, Methods for analysis of organic substances in water: U.S. Geological Survey Techniques of WaterResources Investigations, book 5, chap. A3, $40 \mathrm{p}$.

Hardy, M.A., Leahy, P.P., and Alley, W.M., 1989, Well installation and documentation and ground-water sampling protocols for the pilot
National Water-Quality Assessment Program: U.S. Geological Survey Open-File Report 89-396, 36 p.

Hem, J.D., 1985, Study and interpretation of chemical characteristics of natural water: U.S. Geological Survey Water-Supply Paper 2254, $264 \mathrm{p}$.

Jones, B.E., 1987, Quality control manual of the U.S. Geological Survey's National Water Quality Laboratory: U.S. Geological Survey Open-File Report 87-457, 17 p.

Knobel, L.L., and Mann, L.J., 1993, Sampling for purgeable organic compounds using positivedisplacement piston and centrifugal submersible pumps-a comparative study: Ground Water Monitoring Review, Spring 1993, p. 142-148.

Ludtke, A.S., Woodworth, M.T., and Marsh, P.S., 2000, Quality-assurance results for routine water analyses in U.S. Geological Survey Laboratories, water year 1998: U.S. Geological Survey Water-Resources Investigations Report 00-4176, 198 p.

Maloney, T.J., Ludtke, A.S., Krizman, T.L., 1993, Quality assurance for routine water analysis in the laboratories of the U.S. Geological Survey for water year 1990: U.S. Geological Survey Water-Resources Investigations Report 934082, $145 \mathrm{p}$.

Mann, L.J., 1996, Quality-assurance plan and field methods for quality-of-water activities, U.S. Geological Survey, Idaho National Engineering Laboratory, Idaho: U.S. Geological Survey Open-File Report 96-615 (DOE/ID22132), $37 \mathrm{p}$.

Pritt, J.W., 1989, Quality assurance of sample containers and preservatives at the U.S. Geological Survey National Water Quality Laboratory, in Pederson, G.L., and Smith, M.M., compilers, U.S. Geological Survey Second National Symposium on Water Quality-abstracts of the technical sessions: U.S. Geological Survey Open-File Report 89-409, $111 \mathrm{p}$. 
Pritt, J.W., and Raese, J.W., eds., 1995, Quality assurance/quality control manual-National Water Quality Laboratory: U.S. Geological Survey Open-File Report 95-443, 35 p.

Quanterra Environmental Services, 1998, Quality Assurance Management Plan for environmental services, revision 3: Quanterra Environmental Services [variously paged].

Rose, D.L., and Schroeder, M.P., 1995, Methods of analysis by the U.S. Geological Survey National Water Quality Laboratory-determination of volatile organic compounds in water by purge and trap capillary gas chromatography/mass spectrometry: U.S. Geological Survey Open-File Report 94-708, 26 p.

Stevens, H.H., Jr., Ficke, J.F., and Smoot, G.F., 1975, Water temperature-influential factors, field measurement, and data presentation: U.S. Geological Survey Techniques of WaterResources Investigations, book 5, chap. D1, $65 \mathrm{p}$.

Thatcher, L.L., Janzer, V.J., and Edwards, K.W., 1977, Methods for determination of radioactive substances in water and fluvial sediments: U.S. Geological Survey Techniques of WaterResources Investigations, book 5, chap. A5, $95 \mathrm{p}$.

Timme, P.J., 1995, National Water Quality Laboratory, 1995 services catalog: U.S. Geological Survey Open-File Report 95-352, 120 p.

U.S. Department of Energy, 1995, Radiochemistry manual, revision 10: Idaho Falls, Idaho, U.S. Department of Energy, Radiological and Environmental Sciences Laboratory [variously paged].

U.S. Environmental Protection Agency,1994a, Guidance for the data quality objectives process: U.S. Environmental Protection Agency Report No. 600R-96/005 [variously paged].

1994b, EPA drinking water regulations and health advisories: U.S. Environmental Protection Agency, Office of Water, Report No. 822 $\mathrm{R}-94-001,11 \mathrm{p}$.
1987, Annual report, fiscal year 1986 - methods validation report (radiation): U.S. Environmental Protection Agency Report No. EPA/600/x-87/128, 55 p.

2000, Protection of environment, Code of Federal Regulations 40: Office of the Federal Register, National Archives and Records Administration, pts. 136-149, $901 \mathrm{p}$.

Wegner, S.J., 1989, Selected quality assurance data for water samples collected by the U.S. Geological Survey, Idaho National Engineering Laboratory, 1980 to 1988: U.S. Geological Survey Water-Resources Investigations Report 89-4168 (DOE/ID-22085), 91 p.

Wershaw, R.L., Fishman, M.J., Grabbe, R.R., and Lowe, L.E., 1987, Methods for the determination of organic substances in water and fluvial sediments: U.S. Geological Survey Techniques of Water-Resources Investigations, book 5, chap. A3, 80 p.

Wilde, F.D., Radtke, D.B., Gibs, J., and Iwatsubo, R.T., 1998, National field manual for the collection of water-quality data: U.S. Geological Survey Techniques of Water-Resources Investigations, book 9 [variously paged].

Williams, L.M., 1996, Evaluation of quality assurance/quality control data collected by the U.S. Geological Survey for water-quality activities at the Idaho National Engineering Laboratory, Idaho, 1989 through 1993: U.S. Geological Survey Water-Resources Investigations Report 96-4148 (DOE/ID-22129), 115 p.

1997, Evaluation of quality assurance/quality control data collected by the U.S. Geological Survey for water-quality activities at the Idaho National Engineering Laboratory, Idaho, 1994 through 1995: U.S. Geological Survey Water-Resources Investigations Report 97-4058 (DOE/ID-22136), 87 p.

Williams, L.M., Bartholomay, R.C., and Campbell, L.J., 1998, Evaluation of quality-assurance/quality-control data collected by the U.S. Geological Survey from wells and springs between the southern boundary of the Idaho National Engineering and Environmental Lab- 
oratory and the Hagerman area, Idaho, 1989 through 1995: U.S. Geological Survey WaterResources Investigations Report 98-4206 (DOE/ID-22150), 83 p.

Wood, W.W., 1981, Guidelines for collection and field analysis of ground-water samples for selected unstable constituents: U.S. Geological Survey Techniques of WaterResources Investigations, book 1, chap. D2, 24 p.
Zaugg, S.D., Sandstrom, M.W., Smith, S.G., and Fehlberg, K.M., 1995, Methods of analysis by the U.S. Geological Survey National Water Quality Laboratory-determination of pesticides in water by $\mathrm{C}-18$ solid-phase extraction and capillary-column gas chromatography/mass spectrometry with selected-ion monitoring: U.S. Geoloigcal Survey OpenFile Report 95-181, 49 p. 
Table 1. Containers and preservatives used for water samples, Idaho National Engineering and Environmental Laboratory and vicinity

[Abbreviations: $\mathrm{mL}$, milliliter; L, liter; $\mathrm{N}$, normal. Symbols: $\mathrm{HNO}_{3}$, nitric acid; $\mathrm{H}_{2} \mathrm{SO}_{4}$, sulfuric acid; $\mathrm{HCl}$, hydrochloric acid; ${ }^{\circ} \mathrm{C}$, degrees Celsius. Analyzing laboratory: NWQL-U.S. Geological Survey's National Water Quality Laboratory; DODEC-Department of Defense Environmental Conservation contract laboratory; RESL_U.S. Department of Energy's Radiological Environmental Sciences Laboratory]

\begin{tabular}{|c|c|c|c|c|c|c|}
\hline \multirow[b]{2}{*}{ Type of constituent } & \multicolumn{2}{|c|}{ Container } & \multicolumn{2}{|c|}{ Preservative } & \multirow{2}{*}{$\begin{array}{l}\text { Other } \\
\text { treatment }\end{array}$} & \multirow{2}{*}{$\begin{array}{l}\text { Analyzing } \\
\text { laboratory }\end{array}$} \\
\hline & Type & Size & Type & Volume & & \\
\hline Anions, dissolved & Polyethylene & $250 \mathrm{~mL}$ & None & None & Filter & NWQL \\
\hline Anions, dissolved & Polyethylene & $1 \mathrm{~L}$ & None & None & Filter & DODEC \\
\hline Cations, dissolved & $\begin{array}{l}\text { Polyethylene, } \\
\text { acid rinsed }\end{array}$ & $250 \mathrm{~mL}$ & Ultrex $\mathrm{HNO}_{3}$ & $2 \mathrm{ml}$ & Filter & NWQL \\
\hline Cations, total & $\begin{array}{l}\text { Polyethylene, } \\
\text { acid rinsed }\end{array}$ & $500 \mathrm{~mL}$ & $\mathrm{HNO}_{3}$ & $2 \mathrm{~mL}$ & None & DODEC \\
\hline Metals, dissolved & $\begin{array}{l}\text { Polyethylene, } \\
\text { acid rinsed }\end{array}$ & $250 \mathrm{~mL}$ & Ultrex $\mathrm{HNO}_{3}$ & $2 \mathrm{ml}$ & Filter & NWQL \\
\hline Metals, total & $\begin{array}{l}\text { Polyethylene, } \\
\text { acid rinsed }\end{array}$ & $500 \mathrm{~mL}$ & $\mathrm{HNO}_{3}$ & $2 \mathrm{~mL}$ & None & DODEC \\
\hline Mercury, dissolved & $\begin{array}{l}\text { Glass, acid } \\
\text { rinsed }\end{array}$ & $250 \mathrm{~mL}$ & $\begin{array}{l}6 \mathrm{~N} \text { OmniTrace } \\
\mathrm{HCl}\end{array}$ & $2 \mathrm{~mL}$ & Filter & NWQL \\
\hline Mercury, total & $\begin{array}{l}\text { Glass, acid } \\
\text { rinsed }\end{array}$ & $250 \mathrm{~mL}$ & $\begin{array}{l}\text { 6N OmniTrace } \\
\mathrm{HCl}\end{array}$ & $2 \mathrm{~mL}$ & None & NWQL \\
\hline Chromium, dissolved & $\begin{array}{l}\text { Polyethylene, } \\
\text { acid rinsed }\end{array}$ & $250 \mathrm{~mL}$ & Ultrex $\mathrm{HNO}_{3}$ & $2 \mathrm{ml}$ & Filter & NWQL \\
\hline Nutrients, dissolved & $\begin{array}{l}\text { Polyethylene, } \\
\text { brown }\end{array}$ & $125 \mathrm{~mL}$ & None & None & Filter, chill $4^{\circ} \mathrm{C}$ & NWQL \\
\hline Nutrients, total & Glass, baked & $500 \mathrm{~mL}$ & $\mathrm{H}_{2} \mathrm{SO}_{4}$ & $2 \mathrm{~mL}$ & Chill, $4^{\circ} \mathrm{C}$ & DODEC \\
\hline $\begin{array}{l}\text { Purgeable organic } \\
\text { compounds }\end{array}$ & Glass, baked & $40 \mathrm{~mL}$ & None & None & Chill, $4^{\circ} \mathrm{C}$ & NWQL \\
\hline $\begin{array}{l}\text { Purgeable organic } \\
\text { compounds }\end{array}$ & Glass & $40 \mathrm{~mL}$ & $\mathrm{HCl}$ & 4 drops & Chill, $4^{\circ} \mathrm{C}$ & DODEC \\
\hline $\begin{array}{l}\text { Semi-volatile organic } \\
\text { compounds }\end{array}$ & Glass, baked & $2 \mathrm{~L}$ & None & None & Chill, $4^{\circ} \mathrm{C}$ & DODEC \\
\hline Total organic halogens & Glass, baked & $250 \mathrm{~mL}$ & $\mathrm{H}_{2} \mathrm{SO}_{4}$ & $1 \mathrm{~mL}$ & Chill, $4^{\circ} \mathrm{C}$ & DODEC \\
\hline Total organic carbon & Glass, baked & $125 \mathrm{~mL}$ & None & None & Chill, $4^{\circ} \mathrm{C}$ & NWQL \\
\hline \multirow[t]{2}{*}{$\begin{array}{l}\text { Gross alpha- and beta- } \\
\text { particle radioactivity }\end{array}$} & $\begin{array}{l}\text { Polyethylene, } \\
\text { acid-rinsed }\end{array}$ & $2 \mathrm{~L}$ & $\mathrm{HNO}_{3}$ & $\begin{array}{l}4 \mathrm{~mL} / \\
\text { bottle }\end{array}$ & Filter & NWQL \\
\hline & $\begin{array}{l}\text { Polyethylene, } \\
\text { acid-rinsed }\end{array}$ & $500 \mathrm{~mL}$ & $\mathrm{HNO}_{3}$ & $2 \mathrm{~mL}$ & None & RESL \\
\hline Pesticides & Glass, baked & $1 \mathrm{~L}$ & None & None & Chill, $4^{\circ} \mathrm{C}$ & NWQL \\
\hline Tritium & Polyethylene & $500 \mathrm{~mL}$ & None & None & None & DODEC \\
\hline
\end{tabular}


Table 1. Containers and preservatives used for water samples, Idaho National Engineering and Environmental Laboratory and vicinity-Continued

\begin{tabular}{|c|c|c|c|c|c|c|}
\hline \multirow[b]{2}{*}{ Type of constituent } & \multicolumn{2}{|c|}{ Container } & \multicolumn{2}{|c|}{ Preservative } & \multirow{2}{*}{$\begin{array}{c}\text { Other } \\
\text { treatment }\end{array}$} & \multirow{2}{*}{$\begin{array}{l}\text { Analyzing } \\
\text { laboratory }\end{array}$} \\
\hline & Type & Size & Type & Volume & & \\
\hline \multirow[t]{3}{*}{ Tritium (cont.) } & Polyethylene & $1 \mathrm{~L}$ & None & None & None & NWQL \\
\hline & Polyethylene & $125 \mathrm{~mL}$ & None & None & None & RESL \\
\hline & Polyethylene & $500 \mathrm{~mL}$ & None & None & None & RESL \\
\hline \multirow[t]{2}{*}{ Strontium-90 } & $\begin{array}{l}\text { Polyethylene, } \\
\text { acid-rinsed }\end{array}$ & $1 \mathrm{~L}$ & $\mathrm{HNO}_{3}$ & $4 \mathrm{~mL}$ & Filter & NWQL \\
\hline & $\begin{array}{l}\text { Polyethylene, } \\
\text { acid-rinsed }\end{array}$ & $500 \mathrm{~mL}$ & $\mathrm{HNO}_{3}$ & $2 \mathrm{~mL}$ & None & RESL \\
\hline \multirow[t]{2}{*}{ Gamma spectroscopy } & $\begin{array}{l}\text { Polyethylene, } \\
\text { acid-rinsed }\end{array}$ & $2 \mathrm{~L}$ & $\mathrm{HNO}_{3}$ & $\begin{array}{l}4 \mathrm{~mL} / \\
\text { bottle }\end{array}$ & Filter & NWQL \\
\hline & $\begin{array}{l}\text { Polyethylene, } \\
\text { acid-rinsed }\end{array}$ & $500 \mathrm{~mL}$ & $\mathrm{HNO}_{3}$ & $2 \mathrm{~mL}$ & None & RESL \\
\hline Transuranics & $\begin{array}{l}\text { Polyethylene, } \\
\text { acid-rinsed }\end{array}$ & $1 \mathrm{~L}$ & $\mathrm{HNO}_{3}$ & $4 \mathrm{~mL}$ & None & RESL \\
\hline
\end{tabular}

Table 2. Maximum contaminant levels of types of radioactivity and selected radionuclides in drinking water

[The maximum contaminant levels were established pursuant to the recommendations of the U.S. Environmental Protection Agency (2000, p. 344) for community water systems and are included for comparison purposes only. The maximum contaminant level given for gross alpha-particle radioactivity includes radium-226 but excludes radon and uranium. The maximum contaminant level given for gross beta-particle and gamma radioactivity excludes radioactivity from natural sources and is included for comparison purposes only. Maximum contaminant levels given for strontium- 90 and tritium are average annual concentrations assumed to produce a total body or organ dose of 4 millirem per year (mrem/yr) of beta-particle radiation. Abbreviation: pCi/L, picocurie per liter]

\begin{tabular}{lc}
\hline Radionuclide or type of radioactivity & Maximum contaminant level \\
\hline Gross alpha-particle radioactivity & $15 \mathrm{pCi} / \mathrm{L}$ \\
Gross beta-particle and gamma radioactivity & $4 \mathrm{mrem} / \mathrm{yr}$ \\
Strontium-90 & $8 \mathrm{pCi} / \mathrm{L}$ \\
Tritium & $20,000 \mathrm{pCi} / \mathrm{L}$ \\
\hline
\end{tabular}


Table 3. Maximum or secondary maximum contaminant levels and minimum reporting levels of selected trace elements in drinking water

[The maximum contaminant levels are for total measurements and were established pursuant to the recommendations of the U.S. Environmental Protection Agency (1994b; 2000, p. 343, 421) for community water systems and are for comparison purposes only. Secondary maximum contaminant levels-in brackets-are from U.S. Environmental Protection Agency (2000, p. 613). Minimum reporting levels are given for all analytical methods used for the INEEL Project Office sample programs. Units are in micrograms per liter $(\mu \mathrm{g} / \mathrm{L})$. Symbols: \#, arsenic has a new maximum contaminant level of $10 \mu \mathrm{g} / \mathrm{L}$ (U.S. Environmental Protection Agency, 2001, written commun.); $\bullet$, maximum contaminant level has not been established; ", lead has an action level of $15 \mu \mathrm{g} / \mathrm{L}$ ]

\begin{tabular}{|c|c|c|}
\hline Trace element & $\begin{array}{l}\text { Maximum or secondary maximum } \\
\text { contaminant level }\end{array}$ & Minimum reporting level \\
\hline Aluminum & [50 to 200] & $1,15,100$ \\
\hline Arsenic\# & 10 & $0.9,1,1.9,10$ \\
\hline Antimony & 6 & $0.048,10$ \\
\hline Barium & 2,000 & $0.7,0.9,1,10$ \\
\hline Beryllium & 4 & $0.06,1.6,2$ \\
\hline Boron & .• & 13 \\
\hline Cadmium & 5 & $0.037,0.11,5,8$ \\
\hline Chromium & 100 & $0.8,1,5,14$ \\
\hline Cobalt & .• & $0.015,13$ \\
\hline Copper & {$[1,000]$} & $0.23,10,20$ \\
\hline Iron & [300] & 10,100 \\
\hline Lead & $*$ & $0.08,1,3,100$ \\
\hline Lithium & .• & 3.9 \\
\hline Manganese & {$[50]$} & $0.1,2.2,3.2,10$ \\
\hline Mercury & 2 & $0.01,0.2,0.23$ \\
\hline Molybdenum & .• & $0.2,34$ \\
\hline Nickel & 100 & $0.06,40$ \\
\hline Selenium & 50 & $2.4,2.6,5$ \\
\hline Silver & {$[100]$} & $0.43,1,7,10$ \\
\hline Strontium & .• & $0.8,1$ \\
\hline Thallium & 2 & $0.9,10$ \\
\hline Uranium & .• & 0.018 \\
\hline Vanadium & .• & 1,10 \\
\hline Zinc & {$[5,000]$} & 1,20 \\
\hline
\end{tabular}


Table 4. Maximum or secondary maximum contaminant levels and minimum reporting levels of selected common ions in drinking water

[The maximum contaminant levels are for total measurements and were established pursuant to the recommendations of the U.S Environmental Protection Agency (2000, p. 343) for community water systems and are for comparison purposes only. Secondary maximum contaminant levels-in brackets-are from U.S. Environmental Protection Agency (2000, p. 613). Minimum reporting levels are given for all analytical methods used for the INEEL Project Office sample programs. Units are in milligrams per liter. Symbol: $\bullet \bullet$, maximum contaminant level has not been established]

\begin{tabular}{|c|c|c|}
\hline Constituent & $\begin{array}{c}\text { Maximum or secondary } \\
\text { maximum contaminant } \\
\text { level }\end{array}$ & Minimum reporting level \\
\hline Bromide & $\bullet$ & 0.01 \\
\hline Calcium & $\bullet$ & $0.011,0.2$ \\
\hline \multirow[t]{2}{*}{ Chloride } & {$[250]$} & $0.08,3.0$ \\
\hline & •• & \\
\hline \multirow[t]{2}{*}{ Fluoride } & 4 & 0.16 \\
\hline & [2] & \\
\hline Magnesium & •• & $0.008,0.2$ \\
\hline Potassium & •• & $0.09,5.0$ \\
\hline Silica & •• & $0.09,0.48$ \\
\hline Sodium & •• & $0.06,5.0$ \\
\hline \multirow[t]{2}{*}{ Sulfate } & {$[250]$} & $0.11,5.0$ \\
\hline & •• & \\
\hline
\end{tabular}

Table 5. Maximum contaminant levels and minimum reporting levels of selected nutrients, organic carbon, and total organic halogens in drinking water

[The maximum contaminant levels are for total measurements and were established pursuant to the recommendations of the U.S. Environmental Protection Agency (2000, p. 42) for community water systems and are for comparison purposes only. Minimum reporting levels are given for all analytical methods used for the INEEL Project Office sample programs. Units are in milligrams per liter. Symbol: ••, maximum contaminant level has not been established]

\begin{tabular}{|c|c|c|}
\hline Constituent & Maximum contaminant level & Minimum reporting leve \\
\hline Ammonia (as nitrogen) & $\bullet \bullet$ & 0.02 \\
\hline Nitrite (as nitrogen) & $\bullet \bullet$ & $0.01,0.5$ \\
\hline Nitrite plus nitrate (as nitrogen) & 10 & $0.05,0.1$ \\
\hline Orthophosphate (as phosphorus) & $\bullet$ & $0.01,0.05$ \\
\hline Total kjeldahl nitrogen & $\bullet$ & 0.5 \\
\hline Dissolved organic carbon & $\bullet$ & 0.1 \\
\hline Total organic carbon & $\bullet$ & $0.1,1$ \\
\hline Total organic halogens & •• & 0.03 \\
\hline
\end{tabular}


Table 6. Maximum contaminant levels and minimum reporting levels of selected insecticides in drinking water

[Abbreviations: MCL, maximum contaminant level; MRL, minimum reporting level; MDL, method detection limit. MCLs were established pursuant to the recommendations of the U.S. Environmental Protection Agency (2000, p. 420-421) for community water systems and are included for comparison purposes only. MRLs are from Timme (1995). MDLs are from Zaugg and others (1995). Units are in micrograms per liter. Symbols: $\cdot$, MCL has not been established or proposed; "*, chlorthalonil is a fungicide, DNOC is considered an insecticide and herbicide]

\begin{tabular}{|c|c|c|c|c|c|}
\hline \multicolumn{6}{|c|}{ Carbamate insecticides } \\
\hline Insecticide & MCL & MRL & Insecticide & MCL & MRL \\
\hline Aldicarb & 3 & 0.55 & Methomyl & $\bullet$ & 0.017 \\
\hline Aldicarb sulfone & 2 & .10 & Oxamyl & 200 & .018 \\
\hline Aldicarb sulfoxide & 4 & .021 & Propham & $\bullet$ & .035 \\
\hline Methiocarb & $\bullet$ & .026 & Propoxur & $\bullet$ & .035 \\
\hline
\end{tabular}

\begin{tabular}{|c|c|c|c|c|c|c|c|}
\hline \multirow[b]{2}{*}{ Insecticide } & \multicolumn{4}{|c|}{ Additional insecticides } & \multirow[b]{2}{*}{ MCL } & \multirow[b]{2}{*}{ MRL } & \multirow[b]{2}{*}{ MDL } \\
\hline & MCL & MRL & MDL & Insecticide & & & \\
\hline Azinphos methyl- & $\bullet$ & 0.038 & 0.001 & Fonofos & $\bullet$ & 0.008 & 0.003 \\
\hline Carbaryl (Sevin) & .• & .046 & .003 & $\mathrm{HCH}$, alpha- & .. & .007 & .002 \\
\hline Carbofuran & 40 & .12 & .003 & $\mathrm{HCH}$, gamma- (Lindane) & 0.2 & .011 & .004 \\
\hline Chlorpyrifos & $\bullet$ & .005 & .004 & Hydroxycarbofuran, 3- & •. & .014 & .014 \\
\hline${ }^{* *}$ Chlorthalonil & .• & .48 & .035 & Malathion & •. & .010 & .005 \\
\hline DDE, p,p'- & $\bullet$ & .010 & .006 & Parathion, ethyl- & .• & .022 & .004 \\
\hline Diazinon & •• & .008 & .002 & Parathion, methyl- & $\bullet$ & .035 & .006 \\
\hline Dieldrin & •• & .008 & .001 & Permethrine, cis- & .• & .019 & .005 \\
\hline Dinoseb & .• & .035 & .035 & Phorate & .. & .011 & .002 \\
\hline Disulfoton & .• & .028 & .017 & Propargite I \& II & $\bullet$ & .006 & .013 \\
\hline **DNOC & .• & .42 & .035 & Terbufos & •• & .012 & .013 \\
\hline Ethoprop & •. & .012 & .003 & & & & \\
\hline
\end{tabular}


Table 7. Maximum contaminant levels and minimum reporting levels of chlorophenoxy-acid herbicides and other herbicides in drinking water

[Abbreviations: MCL, maximum contaminant level; MRL, minimum reporting level; MDL, method detection limit. MCLs were established pursuant to the recommendations of the U.S. Environmental Protection Agency (2000, p. 420-421) for community water systems and are included for comparison purposes only. MRLS are from Timme (1995). MDLs are from Zaugg and others (1995). Units are in micrograms per liter. Symbols: $\cdot$, MCL has not been established or proposed; *, samples analyzed using two different laboratory schedules with different MRLs]

\begin{tabular}{lccccc}
\hline & \multicolumn{3}{c}{ Chlorophenoxy-acid herbicides } & & \\
Herbicide & MCL & MRL & Herbicide & MCL & MRL \\
\hline *2,4-D & 70 & 0.01 & *Silvex & 50 & 0.01 \\
(dissolved) & 70 & .15 & (dissolved) &.. & .021 \\
$2,4-D B$ &.. & .24 & $* 2,4,5-T$ &.. & .01 \\
$2,4-D P$ &.. & .01 & (dissolved) &.. & .035 \\
\hline
\end{tabular}

\begin{tabular}{|c|c|c|c|c|c|c|c|}
\hline \multirow[b]{2}{*}{ Herbicide } & \multirow[b]{2}{*}{ MCL } & \multirow[b]{2}{*}{ MRL } & \multicolumn{2}{|c|}{ Other herbicides } & \multirow[b]{2}{*}{ MCL } & \multirow[b]{2}{*}{ MRL } & \multirow[b]{2}{*}{ MDL } \\
\hline & & & MDL & Herbicide & & & \\
\hline Acetochlor & 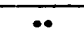 & 0.009 & 0.002 & *Linuron & $\ddot{\bullet}$ & 0.039 & 0.002 \\
\hline Acifluorfen & .• & .035 & .035 & (dissolved) & .. & .018 & .018 \\
\hline Alachlor & 2 & .009 & .002 & $\mathrm{MCPA}$ & .• & .17 & .050 \\
\hline Atrazine & 3 & .017 & .001 & MCPB & .• & .14 & .035 \\
\hline Atrazine, desethyl- & .• & .007 & .002 & Metolachlor & .• & .009 & .002 \\
\hline Benfluralin & •• & .013 & .002 & Metribuzin & .. & .012 & .004 \\
\hline Bentazon & .. & .014 & .014 & Molinate & .• & .007 & .004 \\
\hline Bromacil & $\bullet$ & .035 & .035 & Napropamide & .• & .010 & .003 \\
\hline Bromoxynil & •• & .035 & .035 & Neburon & .• & .015 & .015 \\
\hline Butylate & $\bullet$ & .008 & .002 & Norflurazon & .. & .024 & .024 \\
\hline Chloramben & .. & .42 & .011 & Oryzalin & .. & .31 & .019 \\
\hline Clopyralid & $\bullet$ & .23 & .050 & Pebulate & .• & .009 & .004 \\
\hline Cyanazine & $\bullet$ & .013 & .004 & Pendimethalin & •• & .018 & .004 \\
\hline${ }^{*}$ DCPA (Dacthal) & .• & .004 & .002 & Picloram & 500 & .050 & .050 \\
\hline (dissolved) & $\bullet$ & .017 & .017 & Prometon & •. & .008 & .018 \\
\hline Dicamba & .. & .035 & .035 & Pronamide & .. & .009 & .003 \\
\hline Dichlobenil & •. & 1.2 & .020 & Propachlor & .. & .015 & .007 \\
\hline Dichlorprop & .• & .032 & .032 & Propanil & .. & .016 & .004 \\
\hline Diethylaniline & .• & .006 & .003 & Simazine & 4 & .008 & .005 \\
\hline Diuron & .. & .020 & .020 & Tebuthiuron & .. & .015 & .010 \\
\hline EPTC (Eptam) & .. & .005 & .002 & Terbacil & .. & .030 & .007 \\
\hline Ethalfluralin & .• & .013 & .004 & Thiobencarb & .. & .008 & .002 \\
\hline Fenuron & .. & .013 & .013 & Triallate & .. & .008 & .001 \\
\hline \multirow[t]{2}{*}{ Fluometuron } & .• & .035 & .035 & Triclopyr & .. & .25 & .050 \\
\hline & & & & Trifluralin & .. & .012 & .002 \\
\hline
\end{tabular}


Table 8. Maximum contaminant levels and minimum reporting levels of selected purgeable organic compounds in drinking water

[Analyses performed by the U.S. Geological Survey National Water Quality Laboratory use an analytical method equivalent to U.S. Environmental Protection Agency method 524.2. Abbreviations: MCL, maximum contaminant level; MRL, minimum reporting level. MCLs were established pursuant to the recommendations of the U.S. Environmental Protection Agency (1994b; 2000, p. 419) for community water systems and are included for comparison purposes only. MRLs are from Timme (1995). Units are in micrograms per liter ( $\mu \mathrm{g} / \mathrm{L})$. Symbols: $\cdot \cdot$, MCL has not been established or proposed; *, total trihalomethanes-which include bromoform, chlorodibromomethane, chloroform, and dichlorobromomethane-in community water systems serving 10,000 or more persons cannot exceed $100 \mu \mathrm{g} / \mathrm{L}$ (U.S. Environmental Protection Agency, 2000, p. 343)]

\begin{tabular}{|c|c|c|c|c|c|}
\hline Compound & MCL & MRL & Compound & MCL & MRL \\
\hline Acrylonitrile & •• & 2.5 & 1,3-Dichloropropane & •. & 0.2 \\
\hline Benzene & 5 & .2 & 2,2-Dichloropropane & •. & .2 \\
\hline Bromobenzene & •• & .2 & cis-1,3-Dichloropropene & •• & .2 \\
\hline Bromochloromethane & •• & .2 & trans-1,3-Dichloropropene & •• & .2 \\
\hline Bromoform & * & .2 & 1,1-Dichloropropene & .• & .2 \\
\hline Bromomethane & •• & .2 & Ethylbenzene & 700 & .2 \\
\hline n-Butylbenzene & .. & .2 & Hexachlorobutadiene & .• & .2 \\
\hline sec-Butylbenzene & •• & .2 & Isopropylbenzene & •• & .2 \\
\hline tert-Butylbenzene & •. & .2 & p-Isopropyltoluene & •. & .2 \\
\hline Carbon tetrachloride & 5 & .2 & Methylene chloride & 5 & .2 \\
\hline Chlorobenzene & 100 & .2 & Methyl tert-butylether & •. & .2 \\
\hline Chlorodibromomethane & * & .2 & Naphthalene & •. & .2 \\
\hline Chloroethane & .• & .2 & n-Propylbenzene & •. & .2 \\
\hline Chloroform & * & .2 & Styrene & 100 & .2 \\
\hline Chloromethane & •• & .2 & 1,1,1,2-Tetrachloroethane & .• & .2 \\
\hline 2-Chlorotoluene & •. & .2 & 1,1,2,2-Tetrachloroethane & •• & .2 \\
\hline 4-Chlorotoluene & .• & .2 & Tetrachloroethylene & 5 & .2 \\
\hline 1,2-Dibromo-3-chloropropane & .2 & 1 & Toluene & 1,000 & .2 \\
\hline 1,2-Dibromoethane & .05 & .2 & 1,2,3-Trichlorobenzene & •• & .2 \\
\hline Dibromomethane & •• & .2 & 1,2,4-Trichlorobenzene & 70 & .2 \\
\hline 1,2-Dichlorobenzene & 600 & .2 & 1,1,1-Trichloroethane & 200 & .2 \\
\hline 1,3-Dichlorobenzene & 600 & .2 & 1,1,2-Trichloroethane & 5 & .2 \\
\hline 1,4-Dichlorobenzene & 75 & .2 & Trichloroethene & 5 & .2 \\
\hline Dichlorobromomethane & * & .2 & Trichlorofluoromethane & •. & .2 \\
\hline Dichlorodifluoromethane & •• & .2 & 1,2,3-Trichloropropane & •• & .2 \\
\hline 1,1-Dichloroethane & .• & .2 & 1,1,2-Trichloro 1,2,2-trifluoroethane & •• & .2 \\
\hline 1,2-Dichloroethane & 5 & .2 & 1,2,4-Trimethylbenzene & .• & .2 \\
\hline cis-1,2-Dichloroethene & 70 & .2 & 1,3,5-Trimethylbenzene & .• & .2 \\
\hline 1,1-Dichloroethene & 7 & .2 & Vinyl chloride & 2 & .2 \\
\hline trans-1,2-dichloroethene & 100 & .2 & Xylenes, total ortho, meta, and para & 10,000 & .2 \\
\hline 1,2-Dichloropropane & 5 & .2 & & & \\
\hline
\end{tabular}




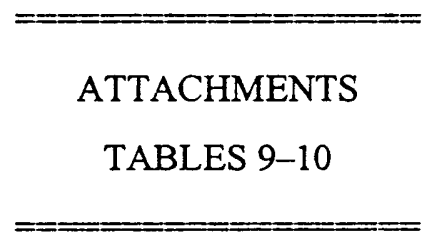




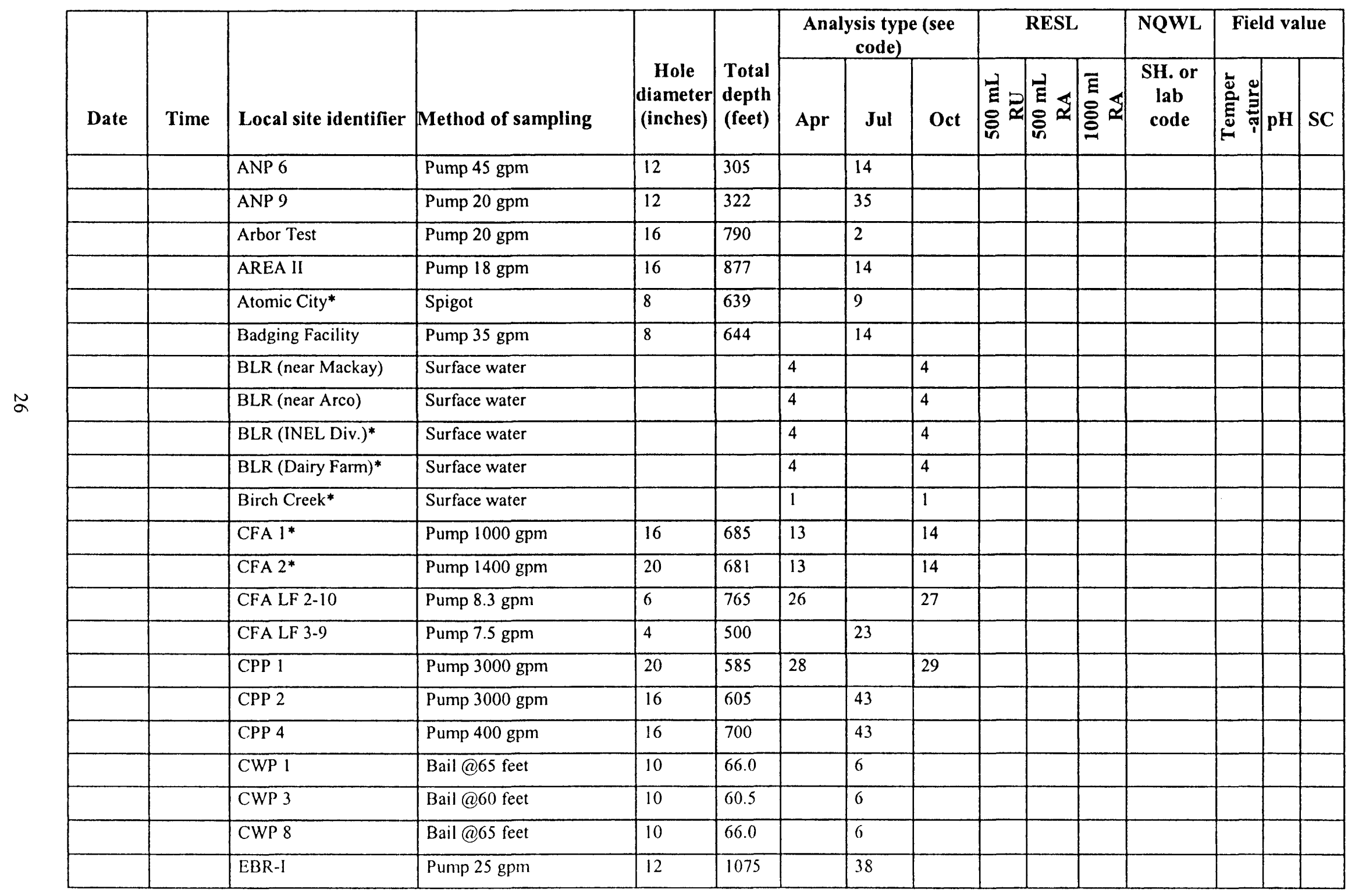


Attachment 1-FIELD SCHEDULE SHOWING WELL AND PUMP INFORMATION AND SAMPLING SCHEDULES FOR SELECTED WELLS AND STREAMFLOW SITES

\begin{tabular}{|c|c|c|c|c|c|c|c|c|c|c|c|c|c|c|c|}
\hline \multirow[b]{2}{*}{ Date } & \multirow[b]{2}{*}{ Time } & \multirow[b]{2}{*}{ Local site identifier } & \multirow[b]{2}{*}{ Method of sampling } & \multirow[b]{2}{*}{$\begin{array}{c}\text { Hole } \\
\text { diameter } \\
\text { (inches) }\end{array}$} & \multirow[b]{2}{*}{$\begin{array}{l}\text { Total } \\
\text { depth } \\
\text { (feet) }\end{array}$} & \multicolumn{3}{|c|}{$\begin{array}{c}\text { Analysis type (see } \\
\text { code) }\end{array}$} & \multicolumn{3}{|c|}{ RESL } & \multirow{2}{*}{\begin{tabular}{|c|} 
NQWL \\
$\begin{array}{c}\text { SH. or } \\
\text { lab } \\
\text { code }\end{array}$ \\
\end{tabular}} & \multicolumn{3}{|c|}{ Field value } \\
\hline & & & & & & Apr & Jul & Oct & $\begin{array}{l}\vec{E} \\
\underline{0} \\
\text { in }\end{array}$ & 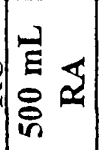 & 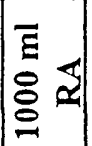 & & 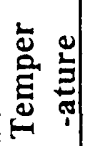 & $\mathrm{pH}$ & SC \\
\hline & & Highway $3^{*}$ & Spigot & 8 & 750 & & 38 & & & & & & & & \\
\hline & & ICPP-MON-A-166 & Pump 6 gpm & 6 & 527 & 47 & & 47 & & & & & & & \\
\hline & & ICPP-MON-A-167 & Pump 4 gpm & 6 & 502 & 47 & & 47 & & & & & & & \\
\hline & & IET Disp & Pump $46 \mathrm{gpm}$ & 20 & 324 & & 14 & & & & & & & & \\
\hline & & Leo Rogers 1 & Pump $20 \mathrm{gpm}$ & 20 & 702 & & 15 & & & & & & & & \\
\hline & & Little Lost River & Surface water & & & 1 & & 1 & & & & & & & \\
\hline & & MTR Test & Pump $26 \mathrm{gpm}$ & 8 & 588 & 11 & & 12 & & & & & & & \\
\hline & & Mud Lake* & Surface & & & 1 & & 1 & & & & & & & \\
\hline & & No Name 1 (Tan Expl.) & Pump 42 gpm & 12 & 550 & & 35 & & & & & & & & \\
\hline & & NRF $6^{* * *}$ & Pump $30 \mathrm{gpm}$ & 8 & 417 & & & & & & & & & & \\
\hline & & NRF $7 * * *$ & Pump $2.5 \mathrm{gpm} \#$ & 10 & 417 & & & & & & & & & & \\
\hline & & NRF $8^{* * *}$ & Pump $30 \mathrm{gpm}$ & 8 & 423 & & & & & & & & & & \\
\hline & & NRF $9^{* * *}$ & Pump 30 gpm & 8 & 422 & & & & & & & & & & \\
\hline & & NRF $10^{* * *}$ & Pump 30 gpm & 8 & 427 & & & & & & & & & & \\
\hline & & NRF $11^{* * *}$ & Pump 30 gpm & 8 & 417 & & & & & & & & & & \\
\hline & & NRF $12^{* * *}$ & Pump 30 gpm & 8 & 421 & & & & & & & & & & \\
\hline & & NRF $13^{* * *}$ & Punip 1 gpm\# & 8 & 425 & & & & & & & & & & \\
\hline & & NPR Test & Pump $28 \mathrm{gpm}$ & 6 & 599 & & 38 & & & & & & & & \\
\hline & & PSTF & Pump 44 gpm & 16 & 322 & & 35 & & & & & & & & \\
\hline & & P\&W 2* & Punp 35 gpm & 10 & 386 & & 25 & & & & & & & & \\
\hline & & $\mathrm{PW}-1$ & Pump 3 gpm & 10 & 117 & 5 & & 13 & & & & & & & \\
\hline & & PW-2 & Bail @115 feet & 10 & 131 & 5 & & 13 & & & & & & & \\
\hline & & $\mathrm{PW}-3$ & Bail (a) $121 \mathrm{fect}$ & 10 & 125 & 5 & & 13 & & & & & & & \\
\hline
\end{tabular}


Attachment 1-FIELD SCHEDULE SHOWING WELL AND PUMP INFORMATION AND SAMPLING SCHEDULES FOR SELECTED WELLS AND STREAMFLOW SITES

\begin{tabular}{|c|c|c|c|c|c|c|c|c|c|c|c|c|c|c|c|}
\hline \multirow[b]{2}{*}{ Date } & \multirow[b]{2}{*}{ Time } & \multirow[b]{2}{*}{ Local site identifier } & \multirow[b]{2}{*}{ Method of sampling } & \multirow[b]{2}{*}{$\begin{array}{c}\text { Hole } \\
\text { diameter } \\
\text { (inches) }\end{array}$} & \multirow[b]{2}{*}{$\begin{array}{l}\text { Total } \\
\text { depth } \\
\text { (feet) }\end{array}$} & \multicolumn{3}{|c|}{$\begin{array}{l}\text { Analysis type (see } \\
\text { code) }\end{array}$} & \multicolumn{3}{|c|}{ RESL } & \multirow{2}{*}{$\begin{array}{c}\text { NQWL } \\
\begin{array}{l}\text { SH. or } \\
\text { lab } \\
\text { code }\end{array}\end{array}$} & \multicolumn{3}{|c|}{ Field value } \\
\hline & & & & & & Apr & Jul & Oct & 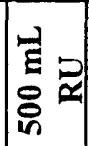 & 喝 & $\begin{array}{l}\bar{z} \\
\bar{\delta} \\
\delta \\
\varrho\end{array}$ & & 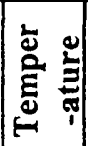 & $\mathrm{pH}$ & SC \\
\hline & & $\begin{array}{l}\mathrm{PW}-4 \\
\end{array}$ & Pump 6 gpm & 10 & 136 & 5 & & 13 & & & & & & & \\
\hline & & PW-5 & Bail@124 & 10 & 124 & 5 & & 13 & & & & & & & \\
\hline & & PW-6 & Bail@125 feet & 10 & 125 & 5 & & 13 & & & & & & & \\
\hline & & PW-8 & Bail @90 & 10 & 166 & 7 & & 17 & & & & & & & \\
\hline & & PW-9 & Pump $5 \mathrm{gpm}$ & 10 & 200 & 7 & & 17 & & & & & & & \\
\hline & & Rifle Range Well & Pump $25 \mathrm{gpm}$ & 6 & 620 & 6 & & 18 & & & & & & & \\
\hline & & RWMC MISA & Pump $3.4 \mathrm{gpm}$ & 6 & 638 & & 44 & & & & & & & & \\
\hline & & RWMC M3S & Pump $3.7 \mathrm{gpm}$ & 6 & 633 & & 23 & & & & & & & & \\
\hline & & RWMC M7S & Pump $4.1 \mathrm{gpm}$ & 6 & 638 & & 23 & & & & & & & & \\
\hline & & RWMCM11S & Pump 6 gpm & 6 & 607 & & 25 & & & & & & & & \\
\hline & & RWMC MI2S & Pump 6 gpm & 6 & 560 & & 25 & & & & & & & & \\
\hline & & RWMC M13S & Pump 6 gpm & 6 & 632 & & 25 & & & & & & & & \\
\hline & & RWMC M14S & Pump 6 gpm & 6 & 633 & & 25 & & & & & & & & \\
\hline & & RWMC Production** & Pump 200 gpm & 16 & 683 & 21 & 42 & 22 & & & & & & & \\
\hline & & Site 4 & Pump 500 gpm & 15 & 496 & & 11 & & & & & & & & \\
\hline & & Site 9 & Pump $25 \mathrm{gpm}$ & 10 & 1057 & & 14 & & & & & & & & \\
\hline & & Site $14^{*}$ & Pump 40 gpm & $\begin{array}{l}8>377 \\
10>340 \\
12<340\end{array}$ & 717 & & 25 & & & & & & & & \\
\hline & & Site 17 & Pump 25 gpm & 20 & 600 & & 14 & & & & & & & & \\
\hline & & Site 19 & Pump 30 gpm & $\begin{array}{l}10>576 \\
18<576\end{array}$ & 865 & & 11 & & & & & & & & \\
\hline & & SPERT I & Pump $400 \mathrm{gpm}$ & 24 & 653 & & 10 & & & & & & & & \\
\hline
\end{tabular}


Attachment 1-FIELD SCHEDULE SHOWING WELL AND PUMP INFORMATION AND SAMPLING SCHEDULES FOR SELECTED WELLS AND STREAMFLOW SITES

\begin{tabular}{|c|c|c|c|c|c|c|c|c|c|c|c|c|c|c|c|}
\hline \multirow[b]{2}{*}{ Date } & \multirow[b]{2}{*}{ Time } & \multirow[b]{2}{*}{ Local site identifier } & \multirow[b]{2}{*}{ Method of sampling } & \multirow[b]{2}{*}{$\begin{array}{c}\text { Hole } \\
\text { diameter } \\
\text { (inches) }\end{array}$} & \multirow[b]{2}{*}{$\begin{array}{c}\text { Total } \\
\text { depth } \\
\text { (feet) }\end{array}$} & \multicolumn{3}{|c|}{$\begin{array}{l}\text { Analysis type (see } \\
\text { code) }\end{array}$} & \multicolumn{3}{|c|}{ RESL } & \multirow{2}{*}{$\begin{array}{c}\text { NQWL } \\
\text { SH. or } \\
\text { lab } \\
\text { code }\end{array}$} & \multicolumn{3}{|c|}{ Field value } \\
\hline & & & & & & Apr & Jul & Oct & 承 & 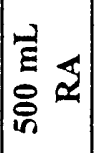 & $\begin{array}{ll}\bar{E} \\
8 \\
8 & \alpha \\
\delta & \end{array}$ & & 总 & pH & SC \\
\hline & & SWP 8 & Bail from bottom of well & 2 & 26 & & 16 & & & & & & & & \\
\hline & & TRA 1 & Pump 3400 gpm & 20 & 600 & & 11 & & & & & & & & \\
\hline & & TRA 3 & Pump 3800 gpm & 20 & 602 & & 11 & & & & & & & & \\
\hline & & TRA 4 & Pump 2000 gpm & 20 & 975 & & 11 & & & & & & & & \\
\hline & & TRA A-13 & Bail from bottom of well & 2 & 59 & 7 & & 18 & & & & & & & \\
\hline & & TRA A-77 & Bail from bottom of well & 2 & 33 & 7 & & 18 & & & & & & & \\
\hline & & TRA Disp. & Pump $25 \mathrm{gpm}$ & 12 & 1267 & 7 & & 19 & & & & & & & \\
\hline & & W.S. for INEL-1 & Pump 30 gpm & 8 & 595 & & 11 & & & & & & & & \\
\hline & & USGS 1 & Pump 19 gpm & 6 & 636 & & 25 & & & & & & & & \\
\hline & & USGS 2 & Pump $16 \mathrm{gpm}$ & 5 & 704 & & 14 & & & & & & & & \\
\hline & & USGS 4 & Pump 40 gpm & 6 & $553 \cdot$ & & 25 & & & & & & & & \\
\hline & & USGS 5 & Pump 5 gpm\# & 6 & 500 & & 38 & & & & & & & & \\
\hline & & USGS 6 & Pump $25 \mathrm{gpm}$ & 6 & 620 & & 14 & & & & & & & & \\
\hline & & USGS 7 & Pump $45 \mathrm{gpm}$ & $\begin{array}{l}4>760 \\
6<760\end{array}$ & 1200 & & 35 & & & & & & & & \\
\hline & & USGS $8^{*}$ & Pump $16 \mathrm{gpm}$ & 6 & 812 & & 25 & & & & & & & & \\
\hline & & USGS 9 & Pump 19 gpm & 8 & 655 & 1 & & 25 & & & & & & & \\
\hline & & USGS $11^{*}$ & Pump $23 \mathrm{gpm}$ & 12 & 704 & 1 & & 25 & & & & & & & \\
\hline & & USGS $12^{* * *}$ & Pump $32 \mathrm{gpm}$ & $\begin{array}{l}10>387 \\
12<387\end{array}$ & 560 & & 31 & & & & & & & & \\
\hline & & USGS $14^{*}$ & Pump $16 \mathrm{gpm}$ & 6 & 751 & 1 & & 4 & & & & & & & \\
\hline & & USGS 15 & Pump $40 \mathrm{gpm}$ & $\begin{array}{l}10>480 \\
16<480\end{array}$ & 610 & & 14 & & & & & & & & \\
\hline
\end{tabular}


Attachment 1-FIELD SCHEDULE SHOWING WELL AND PUMP INFORMATION AND SAMPLING SCHEDULES FOR SELECTED WELLS AND STREAMFLOW SITES

\begin{tabular}{|c|c|c|c|c|c|c|c|c|c|c|c|c|c|c|c|}
\hline \multirow[b]{2}{*}{ Date } & \multirow[b]{2}{*}{ Time } & \multirow[b]{2}{*}{ Local site identifier } & \multirow[b]{2}{*}{ Method of sampling } & \multirow[b]{2}{*}{$\begin{array}{c}\text { Hole } \\
\text { diameter } \\
\text { (inches) }\end{array}$} & \multirow[b]{2}{*}{$\begin{array}{l}\text { Total } \\
\text { depth } \\
\text { (feet) }\end{array}$} & \multicolumn{3}{|c|}{$\begin{array}{l}\text { Analysis type (see } \\
\text { code) }\end{array}$} & \multicolumn{3}{|c|}{ RESL } & \multirow{2}{*}{$\begin{array}{c}\text { NQWL } \\
\text { SH. or } \\
\text { lab } \\
\text { code }\end{array}$} & \multicolumn{3}{|c|}{ Field value } \\
\hline & & & & & & Apr & Jul & Oct & 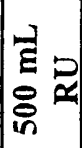 & 疍 & $\begin{array}{l}\overline{\mathbf{E}} \\
\overline{8} \\
\varnothing \\
\varrho\end{array}$ & & 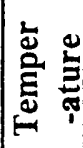 & $\mathrm{pH}$ & SC \\
\hline & & USGS 17 & Pump 32 gpm & $\begin{array}{l}6>416 \\
8<416\end{array}$ & 498 & & 25 & & & & & & & & \\
\hline & & USGS 18 & Pump $30 \mathrm{gpm}$ & 4 & 329 & & 14 & & & & & & & & \\
\hline & & USGS $19^{*}$ & Pump 33 gpm & 6 & 405 & & 25 & & & & & & & & \\
\hline & & USGS 20 & Pump 30 gpm & 6 & 676 & 3 & & 14 & & & & & & & \\
\hline & & USGS 22 & Pump 2.5 gpm\# & 6 & 657 & & 9 & & & & & & & & \\
\hline & & USGS 23 & Pump $25 \mathrm{gpm}$ & 6 & 467 & & 25 & & & & & & & & \\
\hline & & USGS 26 & Pump 40 gpm & 8 & 266 & & 35 & & & & & & & & \\
\hline & & USGS $27^{*}$ & Pump 20 gpm\# & 8 & 312 & & 25 & & & & & & & & \\
\hline & & USGS 29 & Pump 32 gpm & 6 & 422 & & 14 & & & & & & & & \\
\hline & & USGS 31 & Pump 40 gpm & $\begin{array}{l}8>306 \\
10<306\end{array}$ & 428 & & 14 & & & & & & & & \\
\hline & & USGS 32 & Pump $28 \mathrm{gpm}$ & $\begin{array}{l}6>323 \\
10<323\end{array}$ & 392 & & 14 & & & & & & & & \\
\hline & & USGS 34 & Pump 30 gpm & $\begin{array}{l}10>499 \\
13<499\end{array}$ & 700 & 28 & & 29 & & & & & & & \\
\hline & & USGS 35 & Pump 25 gpm & 7 & 578 & 3 & & 14 & & & & & & & \\
\hline & & USGS 36 & Pump $25 \mathrm{gpm}$ & 6 & 567 & 3 & & 14 & & & & & & & \\
\hline & & USGS 37 & Pump 25 gpm & 8 & 573 & 3 & & 20 & & & & & & & \\
\hline & & USGS 38 & Pump 4 gpm\# & $\begin{array}{l}6>505 \\
8<505\end{array}$ & 729 & 28 & & 29 & & & & & & & \\
\hline & & USGS 39 & Pump 25 gpm & $\begin{array}{l}6>507 \\
8<507\end{array}$ & 572 & 3 & & 14 & & & & & & & \\
\hline
\end{tabular}


Attachment 1-FIELD SCHEDULE SHOWING WELL AND PUMP INFORMATION AND SAMPLING SCHEDULES FOR SELECTED WELLS AND STREAMFLOW SITES

\begin{tabular}{|c|c|c|c|c|c|c|c|c|c|c|c|c|c|c|c|}
\hline \multirow[b]{2}{*}{ Date } & \multirow[b]{2}{*}{ Time } & \multirow[b]{2}{*}{ Local site identifier } & \multirow[b]{2}{*}{ Method of sampling } & \multirow[b]{2}{*}{$\begin{array}{c}\text { Hole } \\
\text { diameter } \\
\text { (inches) }\end{array}$} & \multirow[b]{2}{*}{$\begin{array}{l}\text { Total } \\
\text { depth } \\
\text { (feet) }\end{array}$} & \multicolumn{3}{|c|}{$\begin{array}{l}\text { Analysis type (see } \\
\text { code) }\end{array}$} & \multicolumn{3}{|c|}{ RESL } & \multirow{2}{*}{$\begin{array}{c}\text { NQWL } \\
\begin{array}{c}\text { SH. or } \\
\text { lab } \\
\text { code }\end{array}\end{array}$} & \multicolumn{3}{|c|}{ Field value } \\
\hline & & & & & & Apr & Jul & Oct & 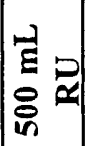 & 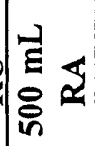 & $\begin{array}{l}\bar{E} \\
8 \\
\stackrel{8}{0}\end{array}$ & & 离 & pH & SC \\
\hline & & USGS 40 & Pump 8 gpm & 6 & 483 & 8 & & 20 & & & & & & & \\
\hline & & USGS 41 & Pump $25 \mathrm{gpm}$ & 6 & 674 & 3 & & 14 & & & & & & & \\
\hline & & USGS 42 & Pump $25 \mathrm{gpm}$ & 6 & 678 & 3 & & 14 & & & & & & & \\
\hline & & USGS 43 & Pump 6 gpm & 6 & 676 & 5 & & 20 & & & & & & & \\
\hline & & USGS 44 & Pump 25 gpm & 6 & 650 & 5 & & 16 & & & & & & & \\
\hline & & USGS 45 & Pump 25 gpm & 6 & 651 & 3 & & 14 & & & & & & & \\
\hline & & USGS 46 & Pump $25 \mathrm{gpm}$ & 6 & 651 & 5 & & 16 & & & & & & & \\
\hline & & USGS 47 & Pump $8 \mathrm{gpm}$ & 6 & 652 & 5 & & 20 & & & & & & & \\
\hline & & USGS 48 & Pump 29 gpm & 6 & 750 & 3 & & 14 & & & & & & & \\
\hline & & USGS 50 & \begin{tabular}{|l|l} 
Pump 0.5 gpm\# & \\
\end{tabular} & 6 & 405 & 5 & & 16 & & & & & & & \\
\hline & & USGS 51 & Pump 4 gpm & 6 & 659 & 3 & & 14 & & & & & & & \\
\hline & & USGS 52 & Pump $30 \mathrm{gpm}$ & 6 & 650 & 3 & & 14 & & & & & & & \\
\hline & & USGS 53 & Bail & 6 & 90 & 7 & & 18 & & & & & & & \\
\hline & & USGS 54 & Pump 4 gpm & 6 & 91 & 7 & & 18 & & & & & & & \\
\hline & & USGS 55 & Pump I gpm & 6 & 79 & 7 & & 17 & & & & & & & \\
\hline & & USGS 56 & Pump 1 gpm & 6 & 80 & 7 & & 18 & & & & & & & \\
\hline & & USGS 57 & Pump $30 \mathrm{gpm}$ & 6 & 732 & 3 & & 16 & & & & & & & \\
\hline & & USGS 58 & Pump 26 gpm & 6 & 503 & 7 & & 18 & & & & & & & \\
\hline & & USGS 59 & Pump 1 gpm & 6 & 657 & 3 & & 14 & & & & & & & \\
\hline & & USGS 60 & Pump 6 gpm & 6 & 117 & 7 & & 17 & & & & & & & \\
\hline & & USGS 61 & Pump 6 gpm & 10 & 123 & 7 & & 17 & & & & & & & \\
\hline & & USGS 62 & Pump 5 gpm & 8 & 165 & 7 & & 17 & & & & & & & \\
\hline & & USGS 63 & Pump $5 \mathrm{gpm}$ & 10 & 97 & 7 & & 17 & & & & & & & \\
\hline
\end{tabular}


Attachment 1-FIELD SCHEDULE SHOWING WELL AND PUMP INFORMATION AND SAMPLING SCHEDULES FOR SELECTED WELLS AND STREAMFLOW SITES

\begin{tabular}{|c|c|c|c|c|c|c|c|c|c|c|c|c|c|c|c|}
\hline \multirow[b]{2}{*}{ Date } & \multirow[b]{2}{*}{ Time } & \multirow[b]{2}{*}{ Local site identifier } & \multirow[b]{2}{*}{ Method of sampling } & \multirow[b]{2}{*}{\begin{tabular}{|c|} 
Hole \\
diameter \\
(inches)
\end{tabular}} & \multirow[b]{2}{*}{$\begin{array}{l}\text { Total } \\
\text { depth } \\
\text { (feet) }\end{array}$} & \multicolumn{3}{|c|}{$\begin{array}{c}\text { Analysis type (see } \\
\text { code) }\end{array}$} & \multicolumn{3}{|c|}{ RESL } & \multirow{2}{*}{$\begin{array}{c}\text { NQWL } \\
\begin{array}{c}\text { SH. or } \\
\text { lab } \\
\text { code }\end{array}\end{array}$} & \multicolumn{3}{|c|}{ Field value } \\
\hline & & & & & & Apr & Jul & Oct & 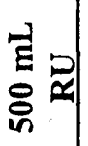 & $\begin{array}{l}\text { है } \\
\text { దે }\end{array}$ & 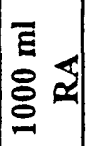 & & 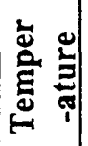 & pH & SC \\
\hline & & USGS $65^{*}$ & Pump 8 gpm & 6 & 498 & 36 & & 37 & & & & & & & \\
\hline & & USGS 66 & Bail@214 feet & 6 & 475 & & 17 & & & & & & & & \\
\hline & & USGS 67 & Pump 8 gpm & 6 & 698 & 3 & & 14 & & & & & & & \\
\hline & & USGS 68 & Pump 1 gpm\# & 10 & 128 & 45 & & 46 & & & & & & & \\
\hline & & USGS 69 & Pump $5 \mathrm{gpm}$ & 10 & 115 & & 17 & & & & & & & & \\
\hline & & USGS 70 & Pump 6 gpm & 8 & 100 & 7 & & 17 & & & & & & & \\
\hline & & USGS 71 & Bail@175 feet & 8 & 184 & 7 & & 17 & & & & & & & \\
\hline & & USGS 72 & Pump 1 gpm & 6 & 177 & & 46 & & & & & & & & \\
\hline & & USGS 73 & Grundfos @100 ft; $1.5 \mathrm{gpm}$ & 6 & 127 & 7 & & 17 & & & & & & & \\
\hline & & USGS 76 & Pump $29 \mathrm{gpm}$ & 6 & 718 & 7 & & 19 & & & & & & & \\
\hline & & USGS 77 & Pump $25 \mathrm{gpm}$ & 6 & 610 & 28 & & 29 & & & & & & & \\
\hline & & USGS 78 & Bail@160 feet & 7 & 204 & & 17 & & & & & & & & \\
\hline & & USGS 79 & Pump $30 \mathrm{gpm}$ & 6 & 702 & 2 & & 11 & & & & & & & \\
\hline & & USGS 82 & Pump $25 \mathrm{gpm}$ & 8 & 700 & 3 & & 14 & & & & & & & \\
\hline & & USGS 83 & Pump $28 \mathrm{gpm}$ & 6 & 752 & & 38 & & & & & & & & \\
\hline & & USGS 84 & Pump $5 \mathrm{gpm}$ & 6 & 505 & 36 & & 37 & & & & & & & \\
\hline & & USGS $85^{*}$ & Pump $23 \mathrm{gpm}$ & 6 & 637 & 3 & & 14 & & & & & & & \\
\hline & & USGS 86 & Pump $19 \mathrm{gpm}$ & 8 & 691 & & 25 & & & & & & & & \\
\hline & & USGS $87^{*}$ & Pump 2 gpm & 6 & 673 & 32 & & 33 & & & & & & & \\
\hline & & USGS 88 & Pump 2 gpm & 6 & 662 & 21 & & 22 & & & & & & & \\
\hline & & USGS 89 & Pump 5 gpm & 6 & 646 & 21 & & 22 & & & & & & & \\
\hline & & USGS 92 & Bail @ 213 feet & 6 & 214 & 21 & & 8 & & & & & & & \\
\hline & & USGS $97^{* * *}$ & Pump 27 gpm & 4 & 510 & & 37 & & & & & & & & \\
\hline
\end{tabular}


Attachment 1-FIELD SCHEDULE SHOWING WELL AND PUMP INFORMATION AND SAMPLING SCHEDULES FOR SELECTED WELLS AND STREAMFLOW SITES

\begin{tabular}{|c|c|c|c|c|c|c|c|c|c|c|c|c|c|c|c|}
\hline \multirow[b]{2}{*}{ Date } & \multirow[b]{2}{*}{ Time } & \multirow[b]{2}{*}{ Local site identifier } & \multirow[b]{2}{*}{ Method of sampling } & \multirow[b]{2}{*}{$\begin{array}{c}\text { Hole } \\
\text { diameter } \\
\text { (inches) }\end{array}$} & \multirow[b]{2}{*}{$\begin{array}{l}\text { Total } \\
\text { depth } \\
\text { (feet) }\end{array}$} & \multicolumn{3}{|c|}{$\begin{array}{c}\text { Analysis type (see } \\
\text { code) }\end{array}$} & \multicolumn{3}{|c|}{ RESL } & \multirow{2}{*}{$\begin{array}{c}\text { NQWL } \\
\text { SH. or } \\
\text { lab } \\
\text { code }\end{array}$} & \multicolumn{3}{|c|}{ Field value } \\
\hline & & & & & & Apr & Jul & Oct & $\begin{array}{ll}2 & \\
8 & 0 \\
8 & 0\end{array}$ & E & 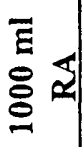 & & 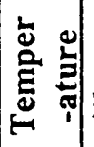 & pH & SC \\
\hline & & USGS $98^{* * *}$ & Pump $25 \mathrm{gpm}$ & 6 & 505 & & 37 & & & & & & & & \\
\hline & & USGS 99*** & Pump 25 gpm & 6 & 450 & & 11 & & & & & & & & \\
\hline & & USGS $100^{*}$ & Pump 10 gpm\# & 6 & 750 & & 11 & & & & & & & & \\
\hline & & USGS 101 & Pump $13 \mathrm{gpm}$ & 6 & 865 & & 25 & & & & & & & & \\
\hline & & USGS $102^{* * *}$ & Pump 29 gpm & 6 & 445 & & 14 & & & & & & & & \\
\hline & & USGS $103^{*}$ & Pump $21 \mathrm{gpm}$ & 8 & 760 & 24 & & 25 & & & & & & & \\
\hline & & USGS $104^{*}$ & Pump 26 gpm & 8 & 700 & 1 & & 10 & & & & & & & \\
\hline & & USGS 105 & Pump 24 gpm & 8 & 800 & 1 & & 25 & & & & & & & \\
\hline & & USGS 106 & Pump $24 \mathrm{gpm}$ & 8 & 760 & 1 & & 9 & & & & & & & \\
\hline & & USGS 107 & Pump 30 gpm & 8 & 690 & & 38 & & & & & & & & \\
\hline & & USGS $108^{*}$ & Pump 24 gpm & 8 & 760 & 1 & & 25 & & & & & & & \\
\hline & & USGS 109 & Pump 22 gpm & 6 & 800 & 1 & & 25 & & & & & & & \\
\hline & & USGS $110 \mathrm{~A}$ & Pump 24 gpm & 10 & 644 & & 25 & & & & & & & & \\
\hline & & USGS 111 & Pump 15 gpm\# & 8 & 595 & 3 & & 14 & & & & & & & \\
\hline & & USGS $112^{*}$ & Pump 30 gpm & 8 & 563 & 3 & & 14 & & & & & & & \\
\hline & & USGS 113 & Pump $25 \mathrm{gpm}$ & 6 & 564 & 3 & & 16 & & & & & & & \\
\hline & & USGS 114 & Pump 10 gpm\# & 6 & 562 & 3 & & 14 & & & & & & & \\
\hline & & USGS $115^{*}$ & Pump 5 gpm & 6 & 581 & 3 & & 14 & & & & & & & \\
\hline & & USGS 116 & Pump $20 \mathrm{gpm}$ & 6 & 580 & 3 & & 14 & & & & & & & \\
\hline & & USGS 117 & Pump $12 \mathrm{gpm \#}$ & 8 & 655 & 21 & & 22 & & & & & & & \\
\hline & & USGS 119 & Pump 3 gpm\# & 8 & 705 & 21 & & 22 & & & & & & & \\
\hline & & USGS $120^{*}$ & Pump 27 gpm & 8 & 705 & 32 & & 33 & & & & & & & \\
\hline & & USGS 121 & Pump 8 gpm & 8 & 475 & 3 & & 14 & & & & & & & \\
\hline
\end{tabular}


Attachment 1-FIELD SCHEDULE SHOWING WELL AND PUMP INFORMATION AND SAMPLING SCHEDULES FOR SELECTED WELLS AND STREAMFLOW SITES

\begin{tabular}{|c|c|c|c|c|c|c|c|c|c|c|c|c|c|c|c|}
\hline \multirow[b]{2}{*}{ Date } & \multirow[b]{2}{*}{ Time } & \multirow[b]{2}{*}{ Local site identifier } & \multirow[b]{2}{*}{ Method of sampling } & \multirow[b]{2}{*}{$\begin{array}{c}\text { Hole } \\
\text { diameter } \\
\text { (inches) }\end{array}$} & \multirow[b]{2}{*}{$\begin{array}{l}\text { Total } \\
\text { depth } \\
\text { (feet) }\end{array}$} & \multicolumn{3}{|c|}{$\begin{array}{c}\text { Analysis type (see } \\
\text { code) }\end{array}$} & \multicolumn{3}{|c|}{ RESL } & \multirow{2}{*}{$\begin{array}{c}\text { NQWL } \\
\text { SH. or } \\
\text { lab } \\
\text { code }\end{array}$} & \multicolumn{3}{|c|}{ Field value } \\
\hline & & & & & & Apr & Jul & Oct & 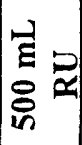 & 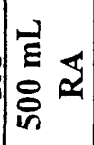 & 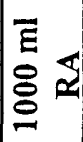 & & 离 & pH & $\mathbf{S C}$ \\
\hline & & USGS 123 & Pump 3 gpm & 8 & 481 & 3 & & 14 & & & & & & & \\
\hline & & USGS $124^{*}$ & Pump 19 gpm & 4 & 800 & 1 & & 10 & & & & & & & \\
\hline & & USGS $125^{*}$ & Pump $21 \mathrm{gpm}$ & 10 & 760 & 1 & & 25 & & & & & & & \\
\hline & & USGS 126A & Pump & 5 & 648 & & 25 & & & & & & & & \\
\hline & & USGS 126B & Pump & 10 & 452 & & 25 & & & & & & & & \\
\hline & & USGS 127 & Pump 25 gpm & 10 & 596 & 26 & & 27 & & & & & & & \\
\hline & & USGS 128 & Pump $23 \mathrm{gpm}$ & $\begin{array}{l}4.5>533 \\
6.5<533\end{array}$ & 618 & 23 & & 23 & & & & & & & \\
\hline
\end{tabular}

*Well is sampled with someone from the State of Idaho's INEEL Oversight Program

**Well is sampled monthly for organics - SH1380

***Well is sampled 3 times a year for the NRF study-Mar, July, Nov.

\# Indicates well needs to be cut back to pump rate indicated; all other pump rates are approximate. 
Codes for types of analyses (number of bottles needed in parenthesis)

1. ${ }^{3} \mathrm{H}, \mathrm{Cl}^{-}(2)$

2. ${ }^{3} \mathrm{H}, \mathrm{Cl}, \mathrm{Cr}(3)$

3. ${ }^{3} \mathrm{H},{ }^{90} \mathrm{Sr}, \mathrm{Cl}^{-}(3)$

4. ${ }^{3} \mathrm{H}, \mathrm{Cl}, \alpha, \beta, \Upsilon \operatorname{Spec}(4)$

5. ${ }^{3} \mathrm{H},{ }^{90} \mathrm{Sr}, \Upsilon \mathrm{Spec}, \mathrm{Cl}^{-}(3)$

$6 .{ }^{3} \mathrm{H},{ }^{90} \mathrm{Sr}, \mathrm{Cl}, \mathrm{Cr}, \mathrm{SO}_{4}^{-}{ }^{-}(4)$

7. ${ }^{3} \mathrm{H},{ }^{90} \mathrm{Sr}, \Upsilon \mathrm{Spec}, \mathrm{Cl}_{3}{ }^{\circ}, \mathrm{Cr}(4)$

8. ${ }^{3} \mathrm{H},{ }^{90} \mathrm{Sr}, \Upsilon \mathrm{Spec},{ }^{241} \mathrm{Am},{ }^{238} \mathrm{Pu},{ }^{239,240} \mathrm{Pu}, \mathrm{Cl}^{-}(3)$

9. ${ }^{3} \mathrm{H}, \mathrm{Cl}^{-}, \mathrm{Na}^{+}(3)$

10. ${ }^{3} \mathrm{H}, \mathrm{Cl}^{-}, \mathrm{Na}^{+}, \mathrm{NO}_{3}^{-}(4)$

11. ${ }^{3} \mathrm{H}, \mathrm{Cl}, \mathrm{Cr}, \mathrm{Na}^{+}, \mathrm{SO}_{4}{ }^{-*}$ (3)

12. ${ }^{3} \mathrm{H}, \mathrm{Cl}+\mathrm{Cr}, \mathrm{Na}^{+}, \mathrm{NO}_{3}^{-}, \mathrm{SO}_{4}{ }^{--}(4)$

13. ${ }^{3} \mathrm{H},{ }^{90} \mathrm{Sr}, \mathrm{Cl}^{-}, \mathrm{Na}^{+}, \mathrm{SO}_{4}^{-}{ }^{-}(4)$

14. ${ }^{3} \mathrm{H},{ }^{90} \mathrm{Sr}, \mathrm{Cl}^{-}, \mathrm{Na}^{+}, \mathrm{NO}_{3}^{-}, \mathrm{SO}_{4}^{--}(5)$

15. ${ }^{3} \mathrm{H}, \alpha, \beta, \Upsilon \mathrm{Spec}, \mathrm{Cl}^{-}, \mathrm{Na}^{+}(5)$

16. ${ }^{3} \mathrm{H},{ }^{90} \mathrm{Sr}, \Upsilon \mathrm{Spec}, \mathrm{Cl}^{-}, \mathrm{Na}^{+}, \mathrm{NO}_{3}{ }^{-}, \mathrm{SO}_{4}^{-}{ }^{-}(5)$

17. ${ }^{3} \mathrm{H},{ }^{90} \mathrm{Sr}, \mathrm{Cl}^{-}, \mathrm{Cr}, \mathrm{Na}^{+}, \mathrm{SO}_{4}^{--}(4)$

18. ${ }^{3} \mathrm{H},{ }^{90} \mathrm{Sr}, \Upsilon \mathrm{Spec}, \mathrm{Cl}, \mathrm{Cr}, \mathrm{Na}^{+}, \mathrm{SO}_{4}{ }^{-}(4)$

19. ${ }^{3} \mathrm{H},{ }^{90} \mathrm{Sr}, \Upsilon \mathrm{Spec}, \mathrm{Cl}, \mathrm{Cr}, \mathrm{Na}^{+}, \mathrm{NO}_{3}^{-}, \mathrm{SO}_{4}{ }^{--}(5)$

20. ${ }^{3} \mathrm{H},{ }^{90} \mathrm{Sr}, \Upsilon \mathrm{Spec},{ }^{241} \mathrm{Am},{ }^{238} \mathrm{Pu},{ }^{239.240} \mathrm{Pu}, \mathrm{Cr}, \mathrm{Na}^{+}, \mathrm{NO}_{3}{ }^{-}, \mathrm{SO}_{4}{ }^{-}(5)$

21. ${ }^{3} \mathrm{H},{ }^{90} \mathrm{Sr}, \Upsilon \mathrm{Spec},{ }^{241} \mathrm{Am},{ }^{238} \mathrm{Pu},{ }^{239,240} \mathrm{Pu}, \mathrm{Cl}$, POC's (6)

22. ${ }^{3} \mathrm{H},{ }^{90} \mathrm{Sr}, \Upsilon \mathrm{Spec},{ }^{241} \mathrm{Am},{ }^{238} \mathrm{Pu},{ }^{239,240} \mathrm{Pu}, \mathrm{Cl}^{-}, \mathrm{Na}^{+}, \mathrm{NO}_{3}{ }^{-}, \mathrm{POC}^{\prime} \mathrm{s}, \mathrm{SO}_{4}^{-}{ }^{-}(8)$

23. ${ }^{3} \mathrm{H},{ }^{90} \mathrm{Sr}, \mathrm{Cl}^{-}, \mathrm{NO}_{3}{ }^{-}(4)$

24. ${ }^{3} \mathrm{H}, \alpha, \beta, \Upsilon \mathrm{Spec}, \mathrm{Cl}^{-}, \mathrm{Na}^{+}, \mathrm{Cr}, \mathrm{NO}_{3}^{-}(6)$

25. ${ }^{3} \mathrm{H}, \alpha, \beta, \Upsilon \mathrm{Spec}, \mathrm{Cl}^{-}, \mathrm{Na}^{+}, \mathrm{Cr}, \mathrm{NO}_{3}^{-}, \mathrm{TOC}(7)$

26. ${ }^{3} \mathrm{H},{ }^{90} \mathrm{Sr}, \alpha, \beta, \Upsilon \mathrm{Spec}, \mathrm{Cl}, \mathrm{Na}^{+}, \mathrm{Cr}, \mathrm{NO}_{3}{ }^{-}(6)$

27. ${ }^{3} \mathrm{H},{ }^{90} \mathrm{Sr}, \alpha, \beta, \Upsilon$ Spec, $\mathrm{Cl}^{-}, \mathrm{Na}^{+}, \mathrm{Cr}, \mathrm{NO}_{3}^{-}, \mathrm{TOC}(7)$

28. ${ }^{3} \mathrm{H},{ }^{90} \mathrm{Sr}, \alpha, \beta, \Upsilon \mathrm{Spec},{ }^{241} \mathrm{Am},{ }^{238} \mathrm{Pu},{ }^{239,240} \mathrm{Pu}, \mathrm{Cl}^{-}, \mathrm{Na}^{+}, \mathrm{Cr}, \mathrm{NO}_{3}{ }^{-}, \mathrm{SO}_{4}{ }^{-}, \mathrm{F}^{-}, \mathrm{POC}$ 's (9)

29. ${ }^{3} \mathrm{H},{ }^{90} \mathrm{Sr}, \alpha, \beta, \Upsilon \mathrm{Spec},{ }^{241} \mathrm{Am},{ }^{238} \mathrm{Pu},{ }^{239.240} \mathrm{Pu}, \mathrm{Cl}^{-}, \mathrm{Na}^{+}, \mathrm{Cr}, \mathrm{NO}_{3}{ }^{-}, \mathrm{SO}_{4}{ }^{-}, \mathrm{F}^{-}, \mathrm{POC}$ 's, TOC (10)

30. ${ }^{3} \mathrm{H}, \alpha, \beta, \Upsilon$ Spec, $\mathrm{Cl}^{-}, \mathrm{Na}^{+}, \mathrm{Cr}, \mathrm{NO}_{3}{ }^{-}, \mathrm{SO}_{4}{ }^{-}, \mathrm{POC}$ 's (9)

31. ${ }^{3} \mathrm{H}, \alpha, \beta, \Upsilon \mathrm{Spec}, \mathrm{Cl}^{-}, \mathrm{Na}^{+}, \mathrm{Cr}, \mathrm{NO}_{3}{ }^{-}, \mathrm{SO}_{4}^{-}, \mathrm{POC}$ 's, TOC (10)

32. ${ }^{3} \mathrm{H},{ }^{90} \mathrm{Sr}, \alpha, \beta, \Upsilon \mathrm{Spec},{ }^{241} \mathrm{Am},{ }^{238} \mathrm{Pu},{ }^{239,240} \mathrm{Pu}, \mathrm{Cl}^{-}, \mathrm{Na}^{+}, \mathrm{Cr}, \mathrm{NO}_{3}{ }^{-}, \mathrm{POC}$ 's (9)

33. ${ }^{3} \mathrm{H},{ }^{90} \mathrm{Sr}, \alpha, \beta, \Upsilon$ Spec, ${ }^{241} \mathrm{Am},{ }^{238} \mathrm{Pu},{ }^{239,240} \mathrm{Pu}, \mathrm{Cl}^{\prime}, \mathrm{Na}^{+}, \mathrm{Cr}, \mathrm{NO}_{3}^{-}$, POC's, TOC, $\mathrm{SO}_{4}^{-}{ }^{-}(10)$

34. ${ }^{3} \mathrm{H},{ }^{90} \mathrm{Sr}, \alpha, \beta, \Upsilon \mathrm{Spec}, \mathrm{Cl}^{-}, \mathrm{Na}^{+}, \mathrm{NO}_{3}{ }^{-}$, POC's, $\mathrm{Sb}, \mathrm{Ar}, \mathrm{Cr}, \mathrm{Pb}, \mathrm{Hg}, \mathrm{Ni}, \mathrm{Tl}, \mathrm{Zn}(12)$

35. ${ }^{3} \mathrm{H},{ }^{90} \mathrm{Sr}, \alpha, \beta, \Upsilon \mathrm{Spec}, \mathrm{Cl}^{\circ}, \mathrm{Na}^{+}, \mathrm{NO}_{3}{ }^{-}, \mathrm{POC}$ 's, TOC, Sb, Ar, Cr, Pb, Hg, Ni, Tl, Zn (13)

36. ${ }^{3} \mathrm{H},{ }^{90} \mathrm{Sr}, \alpha, \beta, \Upsilon \mathrm{Spec},{ }^{241} \mathrm{Am},{ }^{238} \mathrm{Pu},{ }^{239,240} \mathrm{Pu}, \mathrm{Cl}^{-}, \mathrm{Na}^{+} \mathrm{Cr}, \mathrm{NO}_{3}{ }^{-}, \mathrm{SO}_{4}^{--}, \mathrm{POC}$ 's, $\mathrm{Al}, \mathrm{Ar}$,

$\mathrm{Ba}, \mathrm{Cd}, \mathrm{Pb}, \mathrm{Mn}, \mathrm{Ni}, \mathrm{Hg}, \mathrm{Se}, \mathrm{Ag}, \mathrm{Zn}$ (12)

37. ${ }^{3} \mathrm{H},{ }^{90} \mathrm{Sr}, \alpha, \beta, \Upsilon \mathrm{Spec},{ }^{241} \mathrm{Am},{ }^{238} \mathrm{Pu},{ }^{239,240} \mathrm{Pu}, \mathrm{Cl}^{-}, \mathrm{Na}^{+}, \mathrm{Cr}, \mathrm{NO}_{3}{ }^{-}, \mathrm{SO}_{4}^{-}, \mathrm{POC}$ 's, TOC, $\mathrm{Al}, \mathrm{Ar}, \mathrm{Ba}, \mathrm{Cd}, \mathrm{Pb}, \mathrm{Mn}, \mathrm{Ni}, \mathrm{Hg}, \mathrm{Se}, \mathrm{Ag}, \mathrm{Zn}$ (13)

38. ${ }^{3} \mathrm{H}, \alpha, \beta, \Upsilon \mathrm{Spec}, \mathrm{Cl}^{-}, \mathrm{Na}^{+}, \mathrm{Cr}, \mathrm{NO}_{3}^{-}, \mathrm{TOC}, \mathrm{POC}$ 's (10)

39. ${ }^{3} \mathrm{H},{ }^{90} \mathrm{Sr}, \mathrm{Cl}^{\prime}, \mathrm{PCC}$ ' $(6)$

40. ${ }^{3} \mathrm{H},{ }^{90} \mathrm{Sr}, \alpha, \beta, \Upsilon$ Spec, ${ }^{241} \mathrm{Am},{ }^{238} \mathrm{Pu},{ }^{239,240} \mathrm{Pu}, \mathrm{NO}_{3}^{-}$, POC's, SH1254 metals + Ar, V, Mo, Hg, and Field alkalinity and D.O. (11)

41. ${ }^{3} \mathrm{H},{ }^{90} \mathrm{Sr}, \alpha, \beta, \Upsilon$ Spec, ${ }^{241} \mathrm{Am},{ }^{238} \mathrm{Pu},{ }^{239,240} \mathrm{Pu}, \mathrm{NO}_{3}{ }^{\circ}, \mathrm{POC}$ 's, SH1254 metals + Ar, V, Mo, Hg, , TOC + D.O. and field alkalinity (12)

42. POC's (3)

43. ${ }^{3} \mathrm{H},{ }^{90} \mathrm{Sr}, \mathrm{Cl}, \mathrm{Cr}, \mathrm{Na}^{+}, \mathrm{NO}_{3}{ }^{-}(5)$

44. ${ }^{241} \mathrm{Am},{ }^{238} \mathrm{Pu},{ }^{239,240} \mathrm{Pu}(1)$

45. ${ }^{3} \mathrm{H},{ }^{90} \mathrm{Sr}, \alpha, \beta, \Upsilon \mathrm{Spec}, \mathrm{Cl}, \mathrm{Cr},+\mathrm{SH} 1281$ metals: $\mathrm{Ar}, \mathrm{Ba}, \mathrm{Cd}, \mathrm{Cr}, \mathrm{Pb}, \mathrm{Hg}, \mathrm{Se}, \mathrm{Ag}(7)$

46. ${ }^{3} \mathrm{H},{ }^{90} \mathrm{Sr}, \alpha, \beta, \Upsilon \mathrm{Spec}, \mathrm{Cl}, \mathrm{Cr}, \mathrm{Na}^{+}, \mathrm{SO}_{4}{ }^{-},+\mathrm{SH} 1281$ metals: $\mathrm{Ar}, \mathrm{Ba}, \mathrm{Cd}, \mathrm{Cr}, \mathrm{Pb}, \mathrm{Hg}, \mathrm{Se}, \mathrm{Ag}(8)$

47. ${ }^{3} \mathrm{H},{ }^{90} \mathrm{Sr}, \Upsilon \mathrm{Spec}, \mathrm{Cl}, \mathrm{Cr}, \mathrm{Na}^{+}, \mathrm{SO}_{4}^{-}, \mathrm{NO}_{3}{ }^{-}, \mathrm{TOC}(6)$ 


\section{Constituent and type of sample}

\begin{tabular}{|c|c|c|c|}
\hline Type of analyses & $\mathrm{Lab}$ & $\begin{array}{l}\text { Size of sample and } \\
\text { schedule or lab code }\end{array}$ & Type of sample treatment \\
\hline${ }^{3} \mathrm{H}(\mathrm{Ru})$ & RESL & $\begin{array}{l}500 \mathrm{~mL} \text { (Apr, Jul); } \\
125 \mathrm{~mL} \text { (Oct) }\end{array}$ & Raw water, unacidified, rinse bottle \\
\hline${ }^{90} \mathrm{Sr}(\mathrm{RA})$ & RESL & $500 \mathrm{~mL}$ & Raw water, preserved with $2 \mathrm{~mL} \mathrm{HNO}_{3}$, no rinse \\
\hline${ }^{90} \mathrm{Sr}, \Upsilon \mathrm{Spec}(\mathrm{RA})$ & RESL & $500 \mathrm{~mL}$ & Raw water, preserved with $2 \mathrm{~mL} \mathrm{HNO}_{3}$, no rinse \\
\hline${ }^{241} \mathrm{Am},{ }^{238} \mathrm{Pu},{ }^{239,240} \mathrm{Pu}(\mathrm{RA})$ & RESL & $500 \mathrm{~mL}$ & Raw water, preserved with $2 \mathrm{~mL} \mathrm{HNO}_{3}$, no rinse \\
\hline${ }^{90} \mathrm{Sr}, \Upsilon \mathrm{Spec},{ }^{241} \mathrm{Am},{ }^{238} \mathrm{Pu},{ }^{239,240} \mathrm{Pu}(\mathrm{RA})$ & RESL & IL & Raw water, preserved with $4 \mathrm{~mL} \mathrm{HNO}_{3}$, no rinse \\
\hline$\Upsilon \operatorname{Spec}(\mathrm{RA})$ & RESL & $500 \mathrm{~mL}$ & Raw water, preserved with $2 \mathrm{~mL} \mathrm{HNO}_{3}$, no rinse \\
\hline $\mathrm{Na}^{+*}(\mathrm{FA})$ & NWQL & $250 \mathrm{~mL} ; \mathrm{LC} 675$ & $\begin{array}{l}\text { Filtered, preserved with } 1 \mathrm{~mL} \mathrm{HNO} \text {, or } 2 \mathrm{~mL} \text { Ultrex } \mathrm{HNO}_{3} \text {, } \\
\text { rinse poly bottle }\end{array}$ \\
\hline $\mathrm{NO}_{3}^{-}(\mathrm{FCC})$ & NWQL & $125 \mathrm{~mL} ; \mathrm{SH} 101$ & Filtered, chilled, brown poly bottle, rinse bottle \\
\hline POC's (GCV) & NWQL & (3) $40 \mathrm{~mL} ; \mathrm{SH} 1380$ & Raw water, chilled, unacidified, rinse glass bottle, amber \\
\hline $\mathrm{SO}_{4}{ }^{-* *}(\mathrm{FU})$ & NWQL & $250 \mathrm{~mL} ; \mathrm{LC} 1572$ & Filtered, unacidified, rinse poly bottle \\
\hline $\mathrm{F}^{-* *}(\mathrm{FU})$ & NWQL & $250 \mathrm{~mL} ; \mathrm{LC} 31$ & Filtered, unacidified, rinse poly bottle \\
\hline TOC (TOC) & NWQL & $125 \mathrm{~mL} ; \mathrm{LC} 114$ & Raw water, chilled, unacidified, amber glass bottle, no rinse \\
\hline $\begin{array}{l}\mathrm{Sb}, \mathrm{Cr}, \mathrm{Pb}, \mathrm{Ni}, \mathrm{Zn}(\mathrm{FA}) \\
\mathrm{Ar}, \mathrm{Tl}(\mathrm{FA}) \\
\text { Sp. cond. (RU) }\end{array}$ & NWQL & $\begin{array}{l}250 \mathrm{~mL} ; \mathrm{SH} 1050 \text { and } \\
\text { LC } 2160 \text { and } 2508 \\
250 \mathrm{~mL} ; \mathrm{SH} 1050\end{array}$ & $\begin{array}{l}\text { Filtered, preserved with } 2 \mathrm{~mL} \text { ultrex } \mathrm{HNO}_{3} \text {, rinse poly bottle } \\
\text { Raw water, unacidified, rinse poly bottle }\end{array}$ \\
\hline${ }^{129} \mathrm{I}$ & EML & $1 \mathrm{~L}$ & Filtered, chilled, unacidified, polyseal cap \\
\hline${ }^{36} \mathrm{Cl}$ & EML & $1 \mathrm{~L}$ & Raw water, unacidified, polyseal cap on bottle \\
\hline SH 1254 metals ( FU, FA, RU) & NWQL & $\begin{array}{l}250 \mathrm{~mL} ; \mathrm{SH} 1254 \\
250 \mathrm{~mL} ; \mathrm{SH} 1254+\mathrm{LC} \\
2503,1794,+2509 \\
125 \mathrm{~mL} ; \mathrm{SH} 1254\end{array}$ & $\begin{array}{l}\text { Filtered, unacidified, rinse poly bottle } \\
\text { Filtered, preserved with } 2 \mathrm{ml} \text { Ultrex } \mathrm{HNO}_{3} \text {, rinse poly bottle } \\
\text { Raw water, unacidified, rinse poly bottle }\end{array}$ \\
\hline SH 1281 TLCP metals (RA, RU, RAM) & NWQL & $\begin{array}{l}250 \mathrm{~mL} ; \mathrm{SH} 1281 \\
125 \mathrm{~mL} ; \mathrm{SH} 1281 \\
250 \mathrm{~mL} ; \mathrm{SH} 1281\end{array}$ & $\begin{array}{l}\text { Raw, preserved with } 2 \mathrm{~mL} \text { Ultrex } \mathrm{HNO}_{3} \text {, rinse poly bottle } \\
\text { Raw water, unacidified, rinse poly bottle } \\
\text { Raw water, preserved with } 2 \mathrm{ml} 6 \mathrm{~N} \mathrm{HCl} \text {, rinse clear glass } \\
\text { bottle }\end{array}$ \\
\hline
\end{tabular}

*Analysis can be requested from the same bottle, use $2 \mathrm{ml}$ Ultrex $\mathrm{HNO}_{3}$ to preserve bottle **Analysis can be requested from the same bottle. 
Attachment 2-Data-Quality Objectives for Water Samples Analyzed by the National Water Quality Laboratory

\begin{tabular}{|c|c|c|c|c|}
\hline Constituent & $\begin{array}{l}\text { Minimum reporting level } \\
\text { (micrograms per liter) }\end{array}$ & $\begin{array}{l}\text { Precision } \\
\text { ( } \pm \text { percent) }\end{array}$ & $\begin{array}{l}\text { Accuracy* } \\
\text { (percent) }\end{array}$ & $\begin{array}{c}\text { Lab } \\
\text { code/schedule }\end{array}$ \\
\hline I. Purgeable organic compounds & .2 & 30 & $70-130$ & SH 1380 \\
\hline II. Total organic carbon & 100 & 10 & $90-110$ & LC 114 \\
\hline \multicolumn{5}{|l|}{ III. Inorganic compounds (dissolved) } \\
\hline Aluminum & 1 & 10 & $90-110$ & SH 1050 \\
\hline Antimony & .048 & 10 & $90-110$ & SH 1050 \\
\hline Arsenic & .8 & 10 & $90-110$ & LC 2160 \\
\hline Barium & 1 & 10 & $90-110$ & SH 1050 \\
\hline Beryllium & .06 & 10 & $90-110$ & SH 1050 \\
\hline Cadmium & .037 & 10 & $90-110$ & SH 1050 \\
\hline Calcium & 12 & 10 & $90-110$ & SH 1254 \\
\hline Chromium & 10 & 10 & $90-110$ & LC 722 \\
\hline Cobalt & .015 & 10 & $90-110$ & - SH 1050 \\
\hline Copper & .23 & 10 & $90-110$ & SH 1050 \\
\hline Fluoride & 110 & 10 & $90-110$ & LC 31 \\
\hline Iron & 10 & 10 & $90-110$ & SH 1254 \\
\hline Lead & .08 & 10 & $90-110$ & SH 1050 \\
\hline Magnesium & 8 & 10 & $90-110$ & SH 1254 \\
\hline Manganese & .1 & 10 & $90-110$ & SH 1050 \\
\hline Molybdenum & .2 & 10 & $90-110$ & SH 1050 \\
\hline Nickel & .06 & 10 & $90-110$ & SH 1050 \\
\hline Potassium & 110 & 10 & $90-110$ & SH 1254 \\
\hline Selenium & 2 & 10 & $90-110$ & LC 2161 \\
\hline Silica & 130 & 10 & $90-110$ & SH 1254 \\
\hline Silver & 1 & 10 & $90-110$ & SH 1050 \\
\hline Sodium & 90 & 10 & $90-110$ & LC 675 \\
\hline Thallium & .041 & 10 & $90-110$ & LC 2508 \\
\hline Uranium & .018 & 10 & $90-110$ & SH 1050 \\
\hline Zinc & 1 & 10 & $90-110$ & SH 1050 \\
\hline Mercury & .011 & 10 & $90-110$ & LC 2707 \\
\hline Sulfate & 110 & 10 & $90-110$ & LC 1572 \\
\hline Chloride & 330 & 10 & $90-110$ & LC 1571 \\
\hline Nitrate (as N) & 47 & 10 & $90-110$ & SH 101 \\
\hline Nitrite (as N) & 8 & 10 & $90-110$ & SH 101 \\
\hline Phosphate & 18 & 10 & $90-110$ & SH 101 \\
\hline Ammonia (as $\mathrm{N}$ ) & 41 & 40 & $60-140$ & SH 101 \\
\hline \multicolumn{5}{|l|}{ IV. Organic compounds } \\
\hline Pesticides & variable & 40 & $60-140$ & SH 2001 \\
\hline
\end{tabular}

*Coefficient of variance measured by replicate analysis; precision at 10 percent level. 
Attachment 3-Data-Quality Objectives for Radionuclides in Water Samples Analyzed by the Radiological and Environmental Sciences Laboratory

For each radionuclide concentration, an associated analytical uncertainty, $\mathbf{s}$, is calculated such that there is a 67-percent probability that the true concentration of a radionuclide in a sample is in the range of the reported concentration plus or minus the analytical uncertainty. For example, given an analytical result of $1.0 \pm 0.2 \mathrm{pCi} / \mathrm{L}$ (picocuries per liter), there is a 67-percent probability that the true concentration is in the range of 0.8 to $1.2 \mathrm{pCi} / \mathrm{L}$. Some laboratories report the analytical uncertainty as $2 \mathrm{~s}$, at which there is a 95 -percent probability that the true concentration is in the range of 0.6 to $1.4 \mathrm{pCi} / \mathrm{L}$. Therefore, unlike analyses for most inorganic or organic constituents, the analytical uncertainty is specified for each analysis for a specified radionuclide. The following guidelines for interpreting analytical results are based on an extension of the method described by Currie (1968).

In the analysis for a selected radionuclide, laboratory measurements are made on a target sample and a prepared blank. Instrument signals for the sample and the blank vary randomly. Therefore, it is essential to distinguish between two key aspects of the problem of detection: (1) the instrument signal for the sample must be greater than the signal observed for the blank to make the decision that a selected radionuclide was detected; and (2) an estimation must be made of the minimum radionuclide concentration that will yield a sufficiently large observed signal to make the correct decision of detection or nondetection of that radionuclide most of the time. The first aspect of the problem is a qualitative decision based on an observed signal and a definite criterion for detection. The second aspect of the problem is an intuitive estimation of the detection capabilities of a given measurement process.

In the laboratory, instrument signals must exceed a critical level to make the qualitative decision whether a selected radionuclide was detected. Radionuclide concentrations that equal $1.6 \mathrm{~s}$ meet this criterion; at 1.6s, there is a 95-percent probability that the correct decision-not detected-will be made. Given a large number of samples, up to 5 percent of the samples with true concentrations greater than or equal to $1.6 \mathrm{~s}$, which were concluded as being detected, might not contain the selected radionuclide. These measurements are referred to as false positives and are errors of the first kind in hypothesis testing.

Once the critical level of $1.6 \mathrm{~s}$ has been defined, the minimum detectable concentration may be established. Radionuclide concentrations that equal $3 \mathrm{~s}$ represent a measurement of the minimum detectable concentration. For true concentrations of $3 \mathbf{s}$ or greater, there is a 95 -percent-or-more probability of correctly concluding that a selected radionuclide was detected in a sample. Given a large number of samples, up to 5 percent of the samples with true concentrations greater than or equal to $3 \mathrm{~s}$, which were concluded as being nondetected, could contain the selected radionuclide at the minimum detectable concentration. These measurements are referred to as false negatives and are errors of the second kind in hypothesis testing. Inclusion of the $3 \mathbf{s}$ criterion reduces the probability of a false negative to 5 percent or less.

True radionuclide concentrations between $1.6 \mathrm{~s}$ and $3 \mathrm{~s}$ have larger errors of the second kind. That is, there is a greater-than-5-percent probability of false negative results for samples with true concentrations between $1.6 \mathrm{~s}$ and $3 \mathrm{~s}$, and although the selected radionuclide might not have been detected, such nondetection may not be reliable; at $1.6 \mathrm{~s}$, the probability of false negative is about 50 percent.

These guidelines are based on counting statistics alone and do not include systematic or random errors inherent in laboratory procedures. The values $1.6 \mathrm{~s}$ and $3 \mathrm{~s}$ vary slightly with background or blank counts and with the number of gross counts for individual analyses and for different selected radionuclides. The use of the critical level and minimum detectable concentration aid in the interpretation of analytical results and do not represent absolute concentrations of radioactivity which may or may not have been detected. The minimum detectable concentration should not be confused with the detection limit, which is based on instrument sensitivity, sample volumes, analytical procedures and counting times used in the laboratory. 
Bodnar and Percival (1982) summarized detection limits normally available from the RESL. Special arrangements can be made to achieve smaller detection limits for selected constituents. For example, by using a 5-fold counting time for tritium in water, that is, increasing the counting time from 20 to 100 minutes, the detection limit can be reduced from 0.5 to $0.2 \mathrm{pCi} / \mathrm{mL}$.

Detection limits for selected types of radioactivity and nuclides as a function of sample size and detection method are shown on table 9; the limits are intended as guides to order-of-magnitude sensitivities and, in practice, can easily change by a factor of two or more even for the conditions specified. 
Table 9-Detection limits for selected types of radioactivity and nuclides

[Abbreviation: bkgd, background]

\begin{tabular}{|c|c|c|c|c|c|}
\hline $\begin{array}{c}\text { Type of } \\
\text { radioactivity or } \\
\text { nuclide }\end{array}$ & $\begin{array}{l}\text { Sample } \\
\text { material }\end{array}$ & $\begin{array}{l}\text { Size of sample } \\
\text { (milliliter) }\end{array}$ & $\begin{array}{l}\text { Counting time } \\
\text { (minutes) }\end{array}$ & $\begin{array}{l}\text { Detection method } \\
\text { or instrument }\end{array}$ & $\begin{array}{l}\text { Detection limit } \\
\text { (picocuries per } \\
\text { milliliter) }\end{array}$ \\
\hline Gross alpha & Water & 100 & 60 & Scintillation & $3 \times 10^{-3}$ \\
\hline \multirow[t]{3}{*}{ Gross beta } & Water & 250 & 20 & Low bkgd counter & $5 \times 10^{-3}$ \\
\hline & Water & 100 & 20 & Low bkgd counter & $4 \times 10^{-3}$ \\
\hline & Water & 5 & 20 & Low bkgd counter & 0.1 \\
\hline Po-210 & Water & 100 & 60 & Scintillation & $1 \times 10^{-3}$ \\
\hline $\mathrm{Sr}-90$ & Water & 400 & 50 & Low bkgd counter & $5 \times 10^{-3}$ \\
\hline Th-230 & Water & 500 & 60 & Scintillation & $1 \times 10^{-3}$ \\
\hline Tritium & Water & 10 & 20 & Liquid scintillation & 0.5 \\
\hline U-234 & Water & 1,000 & 1,000 & Alpha spectrometry & $4 \times 10^{-5}$ \\
\hline Th-230 & Water & 1,000 & 1,000 & Alpha spectrometry & $4 \times 10^{-5}$ \\
\hline $\mathrm{Pu}-238$ & Water & 1,000 & 1,000 & Alpha spectrometry & $2 \times 10^{-5}$ \\
\hline Am-241 & Water & 1,000 & 1,000 & Alpha spectrometry & $3 \times 10^{-5}$ \\
\hline $\mathrm{Np}-239$ & Water & 400 & 60 & $\mathrm{Ge}(\mathrm{Li})$ & 0.4 \\
\hline Tc-99 & Water & 400 & 60 & $\mathrm{Ge}(\mathrm{Li})$ & 0.7 \\
\hline $\mathrm{Te}-132$ & Water & 400 & 60 & $\mathrm{Ge}(\mathrm{Li})$ & $6 \times 10^{-2}$ \\
\hline $\mathrm{Pb}-212$ & Water & 400 & 60 & $\mathrm{Ge}(\mathrm{Li})$ & 0.1 \\
\hline Se-75 & Water & 400 & 60 & $\mathrm{Ge}(\mathrm{Li})$ & $8 \times 10^{-2}$ \\
\hline Sb- 125 & Water & 400 & 60 & $\operatorname{Ge}(\mathrm{Li})$ & 0.2 \\
\hline$R u-103$ & Water & 400 & 60 & $\mathrm{Ge}(\mathrm{Li})$ & $1 \times 10^{-2}$ \\
\hline $\mathrm{Tl}-108$ & Water & 400 & 60 & $\operatorname{Ge}(\mathrm{Li})$ & 0.2 \\
\hline Sb-124 & Water & 400 & 60 & $\mathrm{Ge}(\mathrm{Li})$ & 0.1 \\
\hline $\mathrm{Ta}-182$ & Water & 400 & 60 & $\operatorname{Ge}(\mathrm{Li})$ & 0.2 \\
\hline Co-60 & Water & 400 & 60 & $\mathrm{Ge}(\mathrm{Li})$ & $6 \times 10^{-2}$ \\
\hline $\mathrm{Na}-22$ & Water & 400 & 60 & $\operatorname{Ge}(\mathrm{Li})$ & $9 \times 10^{-2}$ \\
\hline $\mathrm{K}-40$ & Water & 400 & 60 & $\mathrm{Ge}(\mathrm{Li})$ & 1 \\
\hline $\mathrm{La}-140$ & Water & 400 & 60 & $\mathrm{Ge}(\mathrm{Li})$ & $7 \times 10^{-2}$ \\
\hline $\mathrm{Co}-56$ & Water & 400 & 60 & $\mathrm{Ge}(\mathrm{Li})$ & $5 \times 10^{-2}$ \\
\hline $\mathrm{Ce}-144$ & Water & 400 & 60 & $\mathrm{Ge}(\mathrm{Li})$ & 0.4 \\
\hline Ce-141 & Water & 400 & 60 & $\mathrm{Ge}(\mathrm{Li})$ & $9 \times 10^{-2}$ \\
\hline $\mathrm{Cr}-51$ & Water & 400 & 60 & $\mathrm{Ge}(\mathrm{Li})$ & 0.6 \\
\hline$[-13]$ & Water & 400 & 60 & $\mathrm{Ge}(\mathrm{Li})$ & $6 \times 10^{-2}$ \\
\hline $\mathrm{Ba}-140$ & Water & 400 & 60 & $\mathrm{Ge}(\mathrm{Li})$ & 0.2 \\
\hline$R u-106$ & Water & 400 & 60 & $\mathrm{Ge}(\mathrm{Li})$ & 0.5 \\
\hline Cs-137 & Water & 400 & 60 & $\mathrm{Ge}(\mathrm{Li})$ & $6 \times 10^{-2}$ \\
\hline $\mathrm{Bi}-212$ & Water & 400 & 60 & $\mathrm{Ge}(\mathrm{Li})$ & 1.0 \\
\hline $\mathrm{Nb}-95$ & Water & 400 & 60 & $\mathrm{Ge}(\mathrm{Li})$ & $6 \times 10^{-2}$ \\
\hline Cs- 134 & Water & 400 & 60 & $\operatorname{Ge}(\mathrm{Li})$ & $6 \times 10^{-2}$ \\
\hline Mo-99 & Water & 400 & 60 & $\mathrm{Ge}(\mathrm{Li})$ & $5 \times 10^{-2}$ \\
\hline $\mathrm{Hg}-203$ & Water & 400 & 60 & $\mathrm{Ge}(\mathrm{Li})$ & $6 \times 10^{-2}$ \\
\hline $\mathrm{Kr}-85$ & Water & 400 & 60 & $\mathrm{Ge}(\mathrm{Li})$ & 21 \\
\hline $\mathrm{Bi}-214$ & Water & 400 & 60 & $\mathrm{Ge}(\mathrm{Li})$ & 0.4 \\
\hline$Z r-95$ & Water & 400 & 60 & $\mathrm{Ge}(\mathrm{Li})$ & $9 \times 10^{-2}$ \\
\hline $\mathrm{Co}-58$ & Water & 400 & 60 & $\mathrm{Ge}(\mathrm{Li})$ & $6 \times 10^{-2}$ \\
\hline $\mathrm{Mn}-54$ & Water & 400 & 60 & $\operatorname{Ge}(\mathrm{Li})$ & $5 \times 10^{-2}$ \\
\hline $\mathrm{Ag}-110$ & Water & 400 & 60 & $\mathrm{Ge}(\mathrm{Li})$ & $7 \times 10^{-2}$ \\
\hline Ac- 228 & Water & 400 & 60 & $\operatorname{Ge}(\mathrm{Li})$ & 0.2 \\
\hline $\mathrm{Fe}-59$ & Water & 400 & 60 & $\mathrm{Ge}(\mathrm{Li})$ & 0.1 \\
\hline $\mathrm{Zn}-65$ & Water & 400 & 60 & $\mathrm{Ge}(\mathrm{Li})$ & 0.1 \\
\hline
\end{tabular}


Attachment 4-Data-Quality Objectives for Water Samples Analyzed by Severn Trent Laboratories

The EPA (1994a) has established six primary analytical data-quality objectives for environmental studies. These objectives are precision, accuracy, representativeness, completeness, comparability, and detectability. Severn Trent Laboratories' (STL) approach to each data-quality objective is given in a report by Quanterra Environmental Services (1998, section 8). The method of analyses, minimum reporting levels, and method detection limits for constituents analyzed by STL for the USGS INEEL Project Office are given on Table 10. 
Table 10. Methods for analyses, minimum reporting levels, and method detection limits for constituents analyzed by Severn Trent Laboratories

\begin{tabular}{|c|c|c|c|}
\hline Constituent & Method for analyses & $\begin{array}{l}\text { Minimum reporting level } \\
\text { (micrograms per liter) }\end{array}$ & $\begin{array}{l}\text { Method detection limits } \\
\text { (micrograms per liter) }\end{array}$ \\
\hline Volatile organic compounds & 524.2 & 1.0 & variable \\
\hline Semi-volatile organic chemicals & 525.2 & variable & variable \\
\hline Total organic carbon & 415.1 & 1,000 & 220 \\
\hline Total organic halogens & $9020 \mathrm{~B}$ & 30 & 7.5 \\
\hline \multicolumn{4}{|c|}{ [Inorganic compounds] } \\
\hline Aluminum & $6010 \mathrm{~B}$ & 100 & 15 \\
\hline Antimony & $6010 \mathrm{~B}$ & 10 & 2.3 \\
\hline Arsenic & $6010 \mathrm{~B}$ & 10 & 5.63 \\
\hline Barium & $6010 \mathrm{~B}$ & 10 & 7.4 \\
\hline Beryllium & $6010 \mathrm{~B}$ & 2 & .77 \\
\hline Cadmium & $6010 \mathrm{~B}$ & 5 & 1.4 \\
\hline Calcium & $6010 \mathrm{~B}$ & 200 & 41 \\
\hline Chloride & $300.0 \mathrm{~A}$ & 3,000 & 100 \\
\hline Chromium & 7191 & 5 & .5 \\
\hline Copper & $6010 \mathrm{~B}$ & 20 & 2.1 \\
\hline Iron & $6010 \mathrm{~B}$ & 100 & 86 \\
\hline Lead & $6010 \mathrm{~B}$ & 3 & 2 \\
\hline Magnesium & $6010 \mathrm{~B}$ & 200 & 48 \\
\hline Manganese & $6010 \mathrm{~B}$ & 10 & 2.6 \\
\hline Mercury & $7470 \mathrm{~A}$ & .2 & .043 \\
\hline Nickel & $6010 \mathrm{~B}$ & 40 & 7.6 \\
\hline Potassium & $6010 \mathrm{~B}$ & 5,000 & 500 \\
\hline Selenium & $6010 \mathrm{~B}$ & 5 & 4.55 \\
\hline Silver & $6010 \mathrm{~B}$ & 10 & 2.8 \\
\hline Sodium & $6010 \mathrm{~B}$ & 5,000 & 560 \\
\hline Sulfate & $300.0 \mathrm{~A}$ & 5,000 & 100 \\
\hline Thallium & $6010 \mathrm{~B}$ & 10 & 7.39 \\
\hline Zinc & $6010 B$ & 20 & 14 \\
\hline Nitrite (as N) & 354.1 & 10 & 2 \\
\hline Nitrite plus Nitrate (as N) & 353.2 & 100 & 10 \\
\hline Phosphorous (as P) & 365.3 & 50 & 15 \\
\hline Total kjeldahl nitrogen & 351.2 & 500 & 71 \\
\hline
\end{tabular}


Attachment 5-Inventory of Water-Quality Field Equipment

\begin{tabular}{lccc}
\hline \multicolumn{1}{c}{ Type of meter } & Model & Manufacturer & Serial number \\
\hline $\mathrm{pH}$ & SA250 & Orion & 4154 \\
$\mathrm{pH}$ & $250 \mathrm{~A}$ & Orion & 004282 \\
$\mathrm{pH}$ & $250 \mathrm{~A}+$ & Orion & 014620 \\
$\mathrm{pH}$ & $250 \mathrm{~A}+$ & Orion & 015522 \\
Specific conductance & 122 & Orion & 0905040 \\
Specific conductance & 122 & Orion & 42556041 \\
Specific conductance & $130 \mathrm{~A}$ & Orion & none \\
Specific conductance & 128 & Orion & 83576051 \\
Dissolved oxygen & 810 & Orion & 003585 \\
Multi parameter & Quanta & Hydrolab & QDO1427 \\
Turbidity meter & $2100 \mathrm{P}$ & Hach & 971200016277 \\
\hline
\end{tabular}


Attachment 6-Auditor's Checklist for Quality-Assurance Field Audits.

\section{QUALITY-ASSURANCE FIELD AUDITS \\ AUDITOR'S CHECKLIST}

\section{Auditor's name}

1. Date Sampler's name

\section{Vehicle:}

Was the vehicle clean and well maintained?

Was the vehicle well stocked?

Were the field computer and printer working properly?
Site Name

$\begin{array}{ll}\text { Yes } & \text { No } \\ \text { Yes } & \text { No } \\ \text { Yes } & \text { No }\end{array}$

3. Site Inspection? Yes No Details

4. Water-level measurement? Yes No

Hold 1

Cut1

Recorded on WL sheet? Yes No

Hold2

Cut2

MP

5. Portable discharge lines rinsed with DI water? Yes No

6. Generator:

$\begin{array}{lcc}\text { Grounded? } & \text { Yes } & \text { No } \\ \text { Parked downwind from well? } & \text { Yes } & \text { No }\end{array}$

7. Time pump started?
Discharge measured? Yes No $\mathrm{Q}=$ Well-bore volume calculated? Yes No $=$ Time readings stabilized?

8. Field safety equipment:

$\begin{array}{lcc}\text { shofety equipment: } & \text { Yes } & \text { No } \\ \text { Bucket? } & \text { Yes } & \text { No } \\ \text { First-Aid Kit? } & \text { Yes } & \text { No } \\ \text { Fire Extinguisher? } & \text { Yes } & \text { No } \\ \text { Eye-wash Kit? } & \text { Yes } & \text { No }\end{array}$

$\begin{array}{lcc}\text { Site-safety Plan? } & \text { Yes } & \text { No } \\ \text { QA Plan? } & \text { Yes } & \text { No } \\ \text { Body-fluids Kit? } & \text { Yes } & \text { No } \\ \text { Life Vest (If required)? } & \text { Yes } & \text { No } \\ \text { Pager and Cell Phone? } & \text { Yes } & \text { No }\end{array}$

9. Constituents?

Number of bottles and designations

\section{Calibrations:}

$\begin{array}{llc}\text { Specific Conductance? } & \text { Yes } & \text { No } \\ \text { pH? } & \text { Yes } & \text { No } \\ \text { Recorded in log books? } & \text { Yes } & \text { No } \\ \text { Other? } & \text { Yes } & \text { No }\end{array}$

No




\section{Field Measurements:}

$\begin{array}{lccc}\text { Temperature, water? } & \text { Yes } & \text { No } & \text { Value }= \\ \text { Temperature, air? } & \text { Yes } & \text { No } & \text { Value }= \\ \text { Specific Conductance? } & \text { Yes } & \text { No } & \text { Value }= \\ \text { pH? } & \text { Yes } & \text { No } & \text { Value }= \\ \text { Other (Specify) } ? & \text { Yes } & \text { No } & \text { Value }=\end{array}$

\section{Sample Collection:}

Time started

Gloves

Filter rinsed with sample water or DI (Circle type of rinsate)?

Air purged from filter?

Bottles rinsed with sample if appropriate?

Order of Filling Bottles? Correct Incorrect

Number of Rinses?

\begin{tabular}{lcc} 
& Yes & No \\
& Yes & No \\
& Yes & No \\
& Yes & No \\
List & & \\
List & & \\
\hline
\end{tabular}

\section{Preservation:}

Safety Equipment?

$\begin{array}{lll}\text { Eye Shielding? } & \text { Yes } & \text { No } \\ \text { Rubber Apron? } & \text { Yes } & \text { No } \\ \text { Protective Gloves? } & \text { Yes } & \text { No } \\ \text { Preservatives Added? } & \text { Yes } & \text { No } \\ \text { Correct Order Followed? } & \text { Yes } & \text { No }\end{array}$

\section{Sample Handling:}

$\begin{array}{lcc}\text { Were Sample Bottles Properly Sealed? } & \text { Yes } & \text { No } \\ \text { Were Sample Bottles Properly Labeled? } & \text { Yes } & \text { No } \\ \text { Were Sample Bottles Properly Stored? } & \text { Yes } & \text { No } \\ \text { Was Proper Security of Sample Bottles Maintained? } & \text { Yes } & \text { No }\end{array}$

\section{Decontamination:}

Were Portable Discharge Lines Rinsed with DI Water Prior to Storage? Yes No

\section{Site Clean-up and Security}

Was the well properly secured after sampling?

Was the Site properly cleaned prior to departure?

$\begin{array}{ll}\text { Yes } & \text { No } \\ \text { Yes } & \text { No }\end{array}$

\section{Paperwork copies?}

Logbook sheet?

Custody forms?

Analytical request forms"?

Water-level sheet?

Calibration logbook sheets?

Other? (Specify

\begin{tabular}{llll}
\multicolumn{2}{c}{ Requested? } & \multicolumn{2}{c}{ Delivered? } \\
Yes & No & Yes & No \\
Yes & No & Yes & No \\
Yes & No & Yes & No \\
Yes & No & Yes & No \\
Yes & No & Yes & No \\
Yes & No & Yes & No
\end{tabular}

\section{Comments}

